\title{
ANALISIS KINERJA REKSA DANA SAHAM DENGAN METODE RAW RETURN, SHARPE, TREYNOR, JENSEN DAN SORTINO
}

\author{
Simforianus $^{1}$; Yanthi Hutagaol ${ }^{2}$
}

\begin{abstract}
Mutual Fund (Reksa Dana) can be used as one of the investment alternatives besides personal saving, time deposit, shares and bond. Mutual fund is an investment that has a form as a collective contract investment and managed by the profesionals. From various mutual funds in Indonesia, the investor should choose the mutual fund that they want to invest in. The problem is the type of indicators that the investor can use to choose the mutual funds. The writer did research with 16 equity-based mutual funds in Indonesia with the period from December 31, 2002 to December 31, 2007. Firstly, the writer measures all mutual funds according to their performance, which is based on raw return, Sharpe, Treynor, Jensen and Sortino. Mutual funds with above average performance are considered as superior mutual funds. Afterwards, whether there is any consistency in the performance is checked by using probabilistic method and Chi Squared test. Then, ranking will be made started with the best to the worst mutual funds. The candidates for the best mutual funds are the mutual funds that achieve the superior level at least three times during the six years of the research period. The best mutual fund is the mutual fund which obtains the highest rank according to the five methods above. Probabilistic method indicates a high consistency level with an average of $71.50 \%$. This result is supported by the chi squared test, where the hyphotesis that stated that there is a consistency between mutual fund performances can be proven. The final result is the rank of equity-based mutual funds in Indonesia. The following is the rank of the mutual funds with superior performance: Fortis Pesona, Schroder Prestasi Plus, Dana Reksa Mawar, Fortis Ekuitas, Trim Kapital, Panin Dana Maksima, Si Dana Saham, Rencana Cerdas dan Bahana Dana Prima.
\end{abstract}

Keywords: equity-based mutual funds, performance, raw return, sharpe, treynor, jensen, sortino

\begin{abstract}
ABSTRAK
Reksa dana dapat dijadikan sebagai salah satu alternatif berinvestasi selain tabungan, deposito, saham dan obligasi. Reksa dana merupakan investasi yang merupakan investadi berbentuk kontrak invetasi kolektif dan dikelolah oleh pihak-pihak yang profesional. Dari sekian banyak reksa dana yang ada di Indonesia, investor perlu memilih pada reksa dana mana mereka akan berinvestasi. Permasalahannya adalah jenis indikator yang dapat

\footnotetext{
1,2 BINUS BUSINESS SCHOOL, BINUS UNIVERSITY, JWC Campus, Jl. Hang Lekir I No. 6, Kebayoran Baru, South Jakarta 12120, y.hutagaol@gmail.com
} 
digunakan oleh investor untuk memilih suatu reksa dana. Penulis melakukan penelitian terhadap 16 reksa dana saham yang ada di Indonesia pada periode 31 Desember 2002 s/d 31 Desember 2007. Pertama-tama penulis memposisikan semua reksa dana sesuai kinerjanya berdasarkan raw return, Sharpe, Treynor, Jensen dan Sortino. Posisi diatas rata-rata dinyatakan sebagai reksa dana yang superior, kemudian ada atau tidak adanya konsistensi kinerja diperoleh dengan menggunakan metode probabilita dan uji chi squared. Selanjutnya akan dibuat peringkat dimulai dari reksa dana terbaik sampai yang terburuk. Reksa dana yang diunggulkan adalah reksa dana yang minimal tiga kali menempati posisi superior selama enam tahun penelitian. Reksa dana terbaik adalah reksa dana yang paling banyak dinyatakan unggul menurut kelima metode. Metode probabilita menunjukkan tingkat konsistensi yang besar dengan rata-rata sebesar 71.50\%. Hasil ini didukung oleh uji chi squared, dimana hipotesis yang menyatakan terdapat konsistensi antara kinerja reksa dana terbukti. Hasil akhir yang diperoleh adalah peringkat reksa dana saham di Indonesia. Berikut peringkat Reksa dana yang berkinerja superior : Fortis Pesona, Schroder Prestasi Plus, Dana Reksa Mawar, Fortis Ekuitas, Trim Kapital, Panin Dana Maksima, Si Dana Saham, Rencana Cerdas dan Bahana Dana Prima.

Kata Kunci : reksa dana saham, kinerja, raw return, sharpe, treynor, jensen, sortino 


\section{PENDAHULUAN}

Masyarakat Indonesia adalah masyarakat penabung. Hal tersebut dapat dilihat dari data jumlah dana pihak ketiga yang parkir di bank-bank sangatlah besar. Berdasarkan data dari Bank Indonesia, simpanan berjangka dan tabungan rupiah hingga Agustus 2007 adalah sebesar 878.493 miliar rupiah atau sebesar 22,19\% dari Produk Dosmestik Bruto tahun 2007. Dengan kondisi perekonomian Indonesia yang semakin baik, dimana pertumbuhan Produk Domestik Bruto (PDB) tahun 2007 meningkat sebesar 6,3 persen terhadap tahun 2006, pertumbuhan PDB tanpa migas pada tahun 2007 mencapai 6,9 persen. Besaran PDB Indonesia pada tahun 2007 atas dasar harga berlaku mencapai Rp 3.957,4 triliun, sedangkan atas dasar harga konstan (tahun 2000) mencapai Rp 1.964,0 triliun. Perekonomian Indonesia pada tahun 2007 mengalami pertumbuhan sebesar 6,3 persen dibanding tahun 2006. Tingkat inflasi yang moderat, yang mana inflasi sebesar 6.59\% sepanjang tahun 2007 mendorong penurunan suku bunga menjadi $8.00 \%$ per 6 Febuari 2007.

Dengan berlakunya Undang Undang No.24/2004 tentang Lembaga Penjaminan Simpanan, dimana per tanggal 22 Maret 2007 nilai simpanan yang dijamin adalah 100 juta rupiah, menambah keresahan bagi deposan yang selama ini melakukan penyimpan dana di bank dan menikmati bunga yang tinggi. Dengan semakin turunnya suku bunga, para deposan mencari alternatif untuk membiakan pundi pundi uangnya.

Reksa dana adalah salah satu instrumen yang sangat menarik perhatian para deposan. Peminat reksa dana sering disebut sebagai investor. Para investor ini menikmati berbagai kelebihan dari reksa dana. Dimana return yang diberikan lebih tinggi daripada deposito berjangka ataupun tabungan tahapan biasanya. Akan tetapi tidak semua investor mengenali instrumen investasi ini dengan baik. Ada berbagai jenis reksa dana, dari reksa dana pasar uang, reksa dana berpendapatan tetap, reksa dana saham hingga reksa dana campuran. Setiap instrumen tersebut memiliki karakteristik dan tingkat resiko yang berbeda.

Menjadi sebuah kesulitan bagi masyarakat awam untuk menentukan produk reksa dana mana yang dipilih. Pilihan jenis reksa dana sudah seperti sebuah pasar swalayan investasi. Jumlah Reksa dana Indonesia masih terus mengalami pertumbuhan di tahun 2007 ini, dari 399 reksa dana pada akhir Desember 2006 menjadi 469 reksa dana per Desember 2007 atau meningkat sebesar 17,54 \% di tahun 2007 ini. Nilai Aktiva Bersih (NAB) reksa dana mengalami kenaikan yang cukup signifikan dari Rp 52,28 triliun pada Desember tahun 2006 menjadi Rp 91,5 triliun pada Desember tahun ini (tanggal 26 Desember 2007) atau meningkat sebesar 75,02\% dari tahun sebelumnya.

Dimana terdapat begitu banyak produk dari setiap jenis reksa dana yang ada di Indonesia dan di kelola oleh manajer investasi yang berbeda. Pemilihan instrumen invetasi reksa dana sangatlah berbeda dengan menabung di bank di deposito berjangka ataupun tabungan tahapan, karena adanya unsur resiko yang akan ditanggung investor pada saat melakukan investasi di reksa dana.

Apakah hanya sebatas tingkat return yang ditawarkan oleh manajer investasi yang menjadi kriteria utama dalam memilih instrumen investasi berupa reksa dana ini? Tentu saja 
tidak, risiko yang menjadi pendamping utama dalam invetasi reksa dana menjadi hal yang penting untuk menjadi kriteria dalam memilih reksa dana. Oleh karena itu, penulis tertarik untuk melakukan analisis mengenai kinerja reksa dana, sehingga dapat menjadi acuan bagi masyarakat umum yang hendak berinvestasi di instrumen reksa dana.

Dalam melakukan analisis, peneliti akan menggunakan beberapa metode untuk mengukur kinerja reksa dana. Adapun metode tersebut adalah Raw Return, Sharpe, Treynor, Jensen dan Sortino. Metode raw return adalah sebuah metode pengukuran kinerja portfolio selama periode tertentu tanpa memperhitungan unsur resiko di dalamnya. Ada tiga metode pengukuran kinerja reksa dana dengan memasukkan unsur risiko yang sering digunakan yakni dengan Sharpe, Treynor, dan Jensen. Sedangkan metode Sortino menggunakan excess return dalam menentukan kinerja portofolio.

\section{RUMUSAN PERMASALAHAN}

Masalah penelitian ini dirumuskan sebagai berikut :

1. Bagaimanakah posisi reksa dana saham di Indonesia sebagai superior dan inferior periode tahun 2002-2007 menurut masing masing metode Raw Return, Sharpe, Treynor, Jensen dan Sortino?

2. Apakah terdapat konsistensi kinerja reksa dana saham di Indonesia metode Raw Return, Sharpe, Treynor, Jensen dan Sortino pada periode tahun 2002 s/d 2007 ?

3. Bagaimanakah peringkat reksa dana saham mana menurut metode Raw Return, Sharpe, Treynor, Jensen dan Sortino pada periode tahun 2002 s/d 2007?

\section{TINJAUAN TEORI}

\section{Pengertian Reksa Dana}

Apa sebenarnya reksadana itu ? Beberapa definisi di bawah ini akan menjelaskannya :

Reksadana adalah wadah yang dipergunakan untuk menghimpun dana dari masyarakat pemodal untuk selanjutnya diinvestasikan dalam portofolio efek oleh Manajer Investasi yang telah mendapat ijin dari Bapepam. (Undang-undang Nomor 8 Tahun 1995, pasal 1 ayat 27)

Menurut Fabozzi \& Modigliani $(2003,65)$ mendefinisikannya sebagai berikut :

Open-end funds, commonly reffered to simply as mutual funds, are portfolios of securities, mainly stocks, bonds, and money market instruments. Investors in mutual funds own a pro rata share of the overall portfolio, which is managed by an investment manager of the mutual fund who buys some securities and sell others. 
Per definisi, reksa dana merupakan suatu perusahaan yang menanamkan modalnya dalam berbagai portofolio saham beragam (diversified portfolio). Perusahaan reksa dana menjual saham kepada pemodal dengan menjanjikan nilai tambah dalam wujud perubahan dividen, capital gain, dan kenaikan net asset value (NAV).

Dengan demikian perusahaan reksa dana merupakan suatu institusi pelayanan keuangan (financial service organization) atau perusahaan pengelola dana. Perusahaan reksa dana menerima titipan uang dari pemegang saham untuk selanjutnya menginvestasikan dana tersebut atas nama pemegang saham dalam suatu portofolio beragam. Dengan kata lain investasi dalam reksa dana mewakili suatu posisi pemilikan dalam suatu sekuritas / surat berharga yang dikelola secara profesional. Apabila pemodal membeli saham di reksa dana, maka investor yang bersangkutan berstatus sebagai pemilik atas bagian portofolio sekuritas perusahaan reksa dana tersebut.

Secara ringkas, konsep reksa dana (mutual funds) merupakan suatu cara mengalihkan pemilikan surat-surat berharga dan manajeman portofolio kepada pengelola uang profesional (professional fund manager). Dengan melakukan investasi melalui pemilikan saham reksa dana berarti seorang investor menikmati diversifikasi investasi yang lebih luas dibandingkan melakukannya secara individual. Pada intinya reksa dana menganut konsep pooled diversification, yang idenya mirip dengan konsep asuransi, dimana sumber dana perorangan dihimpun untuk suatu manfaat bersama.

Di Indonesia, investor umumnya masih melihat investasi portofolio, saham dan obligasi di pasar modal sebagai investasi yang belum tentu mendatangkan hasil yang lebih baik dari investasi pada deposito. Hal ini disebabkan karena banyaknya biaya yang harus ditanggung investor. Biaya-biaya itu seperti biaya transaksi, biaya komisi, pajak pertambahan nilai (PPN) dan pajak dividen.

Dari instrumen dimana reksa dana melakukan investasinya, reksa dana dapat dibagi menjadi empat jenis kategori, yaitu :

\section{1) Reksa Dana Pasar Uang}

Reksa Dana Pasar Uang didefinisikan sebagai reksa dana yang melakukan investasi $100 \%$ pada efek pasar uang. Efek pasar uang merupakan instrumen utang berjangka waktu kurang dari 1 tahun, seperti deposito, SBI, obligasi serta efek utang lainnya.

Reksa Dana Pasar Uang merupakan reksa dana dengan tingkat risiko paling rendah, tetapi di lain pihak potensi keuntungannya juga terbatas. Hasil investasi di Reksa Dana Pasar Uang umumnya sangat mirip dengan tingkat suku bunga deposito, karena hampir sebagian besar portofolio investasinya terdiri dari deposito.

Kelebihan yang dimiliki oleh reksa dana jenis ini adalah dalam hal diversifikasi investasi dan likuiditas yang lebih tinggi. Pencairan dana dapat dilakukan satu hari setelah permohonan disampaikan dan tentunya tingkat bunga yang lebih tinggi dari bank. 


\section{2) Reksa Dana Pendapatan Tetap}

Reksa Dana Pendapatan Tetap adalah reksa dana yang melakukan investasi sekurangkurangnya $80 \%$ dari portofolio yang dikelolanya ke dalam efek bersifat hutang.

Efek bersifat hutang umumnya memberikan penghasilan dalam bentuk bunga, seperti deposito, SBI, obligasi dan instrumen lainnya. Umumnya reksa dana pendapatan tetap di Indonesia memanfaatkan instrumen obligasi sebagai bagian terbesar investasinya.

\section{3) Reksa Dana Saham}

Reksa Dana Saham adalah reksa dana yang melakukan investasi sekurang-kurangnya $80 \%$ dari portofolio yang dikelolanya ke dalam efek bersifat ekuitas (saham).

Berbeda dengan efek pendapatan tetap seperti deposito dan obligasi, investor lebih berorientasi pada pendapatan bunga. Pada efek saham investor akan memperoleh hasil yang lebih tinggi berupa capital gain melalui pertumbuhan harga-harga saham. Selain hasil dari capital gain, efek saham juga memberikan hasil lain berupa dividen.

\section{4) Reksa Dana Campuran}

Tidak seperti ketiga jenis reksa dana yang sudah dijelaskan sebelumnya, reksa dana Campuran dapat melakukan investasinya baik pada efek utang, ekuitas dan instrumen pasar uang dengan porsi alokasi yang lebih fleksibel.

Mengingat komposisinya yang sangat bervariasi, perlu analisis dan informasi yang lebih mendalam sebelum menentukan pilihan pada suatu reksa dana campuran tertentu. Investor harus benar-benar mengetahui, bagaimana komposisi investasi yang terdapat dari reksa dana campuran yang akan dipilih. Hal ini dapat dilakukan dengan mempelajari Prospektus.

\section{Resiko Reksa Dana}

Menurut Cahyono (2002,52-54), reksa dana sebagai sarana investasi memiliki resiko investasi sebagai berikut :

1. Risiko berkurangnya nilai Unit Penyertaan (UP)

Nilai unit penyertaan reksa dana bisa naik dan turun sejalan dengan kenaikan atau penurunan harga efek ekuitas dan efek utang yang menjadi sarana investasi reksa dana tersebut. Penurunan nilai aktiva bersih unit penyertaan reksadana juga bisa terjadi karena adanya biaya biaya yang dikenakan atas reksa dana tersebut.

2. Risiko perubahan kondisi ekonomi dan politik

Bagi Indonesia yangmenganut system ekonomi terbuka, perkembangan politik di luar negeri mempengaruhi perekonomian dan politik nasional. Perubahan politik di suatu Negara ini pada gilirannya juga dapat mempengaruhi pandangan umum terhadap perusahaan- perusahaan di Indonesia, termasuk perusahaan-perusahaan yang tercatat di Bursa efek Indonesia. Akhirnya, pandangan umum tersebut bisa membuat investor melikuidasi portfolio efeknya yang akan menyebabkan penurunan nilai efek tersebut.

3. Risiko likuiditas reksa dana terbuka

Pengelolah investasi wajib membeli kembali unit penyertaan dari investor. Untuk memenuhi kewajiban tersebut pengelolah investasi bisa menjual sebagian 
portfolionya. Resiko likuiditas bisa terjadi jika efek dari portfolio mengalami kesulitan untuk di jual karena faktor penawaran dan permintaan.

4. Risiko Wanprestasi

Risiko ini muncul jika ada pihak terkait seperti emiten, bank kustodia, agen penjual gagl memenuhi kewajibannya. Kegagalan dari pihak terkait dalam melunasi kewajibannya ini dapat mempengaruhi nilai aktiva bersih reksadana. Wanprestasi misalnya dilakukan oleh beberapa penerbit obligasi selama krisis moneter yakni tidak membayar kupon bunga pada waktunya.

5. Risiko berkaitan dengan peraturan

Dalam berinvestasi reksa dana mempunyai batasan-batasan tertentu, misalnya tidak boleh membeli efek di luar negeri dan membeli efek yang di terbitkan oleh emiten melebihi $10 \%$ dari nilai aktiva reksa dana

\section{METODOLOGI}

\section{Kerangka Pikir}

Dalam penulisan ini akan memberikan gambaran hasil penelitian yang dilakukan dalam menyelesaikan masalah pokok yang di bahas, yakni menjelaskan kinerja reksa dana saham kepada para investor. Selain itu, penelitian ini juga untuk mengetahui apakah terdapat konsistensi dengan menggunakan metode Raw return, Sharpe, Treynor, Jensen dan Sortino pada periode tahun 2002-2007. Dari penelitian ini juga dapat diketahui reksa dana mana yang dinyatakan unggul menurut metode Raw return, Sharpe, Treynor, Jensen dan Sortino serta akan dibuat peringkat reksa dana saham dari yang terbaik sampai yang terburuk.

Secara Skematis Kerangka pikir dapat digambarkan sebagai berikut : 


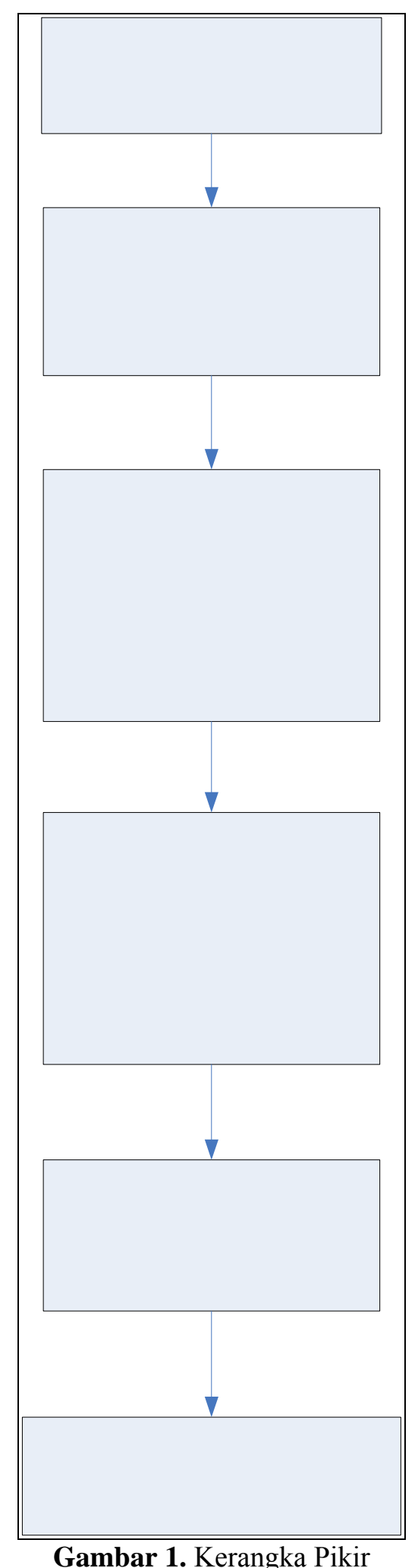

\title{
PENGUMPULAN D, NAB 2002-2007
}

\author{
PURPOSIVE \\ SAMPLING DATA I \\ REKSA DANA SAH \\ $2002-2007$
}

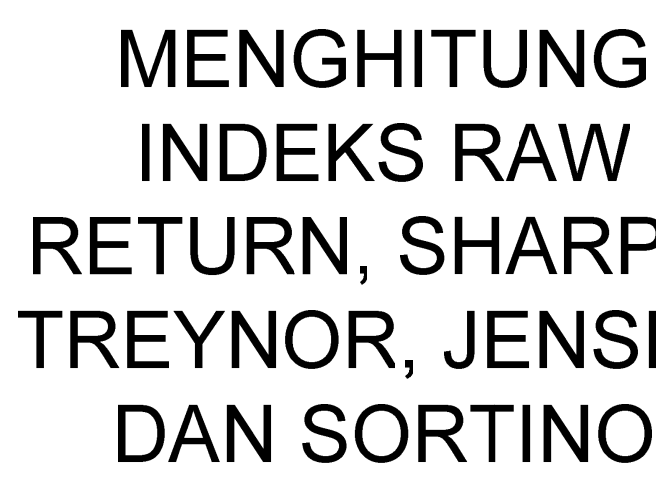




\section{Metode Penelitian}

Metode penelitian yang digunakan adalah :

a. Metode penelitian kepustakaan

Dilakukan dengan membaca serta mengambil data-data dari buku-buku dan artikel-artikel yang menunjang untuk kepentinagn landasan teori dalam mendukung analisis yang dilakukan

b. Metode analisis

Analisis data merupakan hal yang penting untuk dilakukan dalam melakukan sebuah penelitian. Dengan melakukan analisis yang tepat maka data dapat menjadi berarti dan bermanfaat untuk memecahkan masalah yang dihadapi.

Analisis dilakukan dua tahap, yaitu :

1. Pengumpulan data NAB dari reksa dana saham pada periode tahun 31 Desember 2001 sampai dengan 31 desember 2007

2. Mengelolah data NAB dengan menggunakan metode Raw return, Sharpe, Treynor, Jensen dan Sortino

\section{Populasi dan Teknik Pengambilan Sampel}

Populasi adalah keseluruhan unsur yang menjadi subyek suatu penelitian (Aritonang, 1998, 101). Populasi dalam penelitian ini adalah seluruh reksa dana yang berada di pasar.

Metode pelaksanaan sampling dibedakan menjadi metode acak (random) dan tidak acak. Pada metode acak, pemilihan unsur sampel dilakukan sedemikian rupa sehingga semua unsur yang terdapat pada populasi memiliki peluang yang sama untuk terpilih menjadi sampel. (Aritonang R.1998, 105)

Metode pengambilan sampel yang digunakan adalah Teknik Pemilihan Sampel Tak Acak Purposive. Teknik Purposive (bertujuan) ini disebut juga teknik Judgemental. Pada teknik ini unsur populasi yang ditentukan menjadi sampel didasarkan pada tujuan penelitian. Sampel yang dipilih adalah reksa dana yang mempunyai syarat-syarat seperti di bawah ini :

1) Reksa dana yang dijadikan sampel adalah reksa dana saham.

2) Reksa dana saham minimal telah beroperasi pada 31 Desember 2002 (6 tahun).

Dari 23 reksa dana saham yang hadir di pasar pada saat penelitian ini dilakukan, hanya 16 reksa dana yang telah berumur enam tahun.

Tabel 1. Reksa Dana Saham

\begin{tabular}{|r|l|}
\hline No & \multicolumn{1}{|c|}{ Nama Reksa Dana } \\
\hline 1 & ABN AMRO IND. DANA SAHAM \\
\hline 2 & BAHANA DANA PRIMA \\
\hline 3 & BIG NUSANTARA \\
\hline 4 & BIG PALAPA \\
\hline
\end{tabular}




\begin{tabular}{r|l|}
\hline 5 & BNI BERKEMBANG \\
\hline 6 & DANAREKSA MAWAR \\
\hline 7 & FORTIS EKUITAS \\
\hline 8 & FORTIS PESONA \\
\hline 9 & MASTER DINAMIS \\
\hline 10 & NIKKO SAHAM NUSANTARA \\
\hline 11 & PANIN DANA MAKSIMA \\
\hline 12 & PHINISI DANA SAHAM \\
\hline 13 & RENCANA CERDAS \\
\hline 14 & SCHRODER PRESTASI PLUS \\
\hline 15 & SIDANA SAHAM \\
\hline 16 & TRIM KAPITAL \\
\hline
\end{tabular}

\section{Teknik Pengumpulan Data} historis.

Teknik pengumpulan data dilakukan dengan studi kepustakaan dan pengumpulan data

Semua data yang digunakan adalah data sekunder, yaitu data yang telah tersedia, dimana data-data tersebut diperoleh dari berbagai sumber, yaitu :

1) Nilai Aktiva Bersih (NAB) per unit satu bulanan periode tahun 31 Desember 2001 sampai dengan 31 Desember 2007 diperoleh dari Pusat Informasi Reksa dana dan melalui situs internet www.bapepam.go.id/reksadana

2) Indeks Harga Saham Gabungan (IHSG) satu bulanan periode tahun 31 Desember 2001 sampai dengan 31 Desember 2007 diperoleh dari Bursa Efek Indonesia melalui situs internet www.bei.co.id.

3) Suku bunga SBI satu bulanan periode tahun 31 Desember 2001 sampai dengan 31 Desember 2007 diperoleh dari Bank Indonesia melalui situs internet www.bi.go.id.

\section{Teknik Pengolahan Data}

Pengolahan data untuk setiap reksa dana saham dilakukan untuk mengetahui kinerja reksa dana yang bersangkutan, berdasarkan :

\section{Raw Return \\ 2.Sharpe (1964 - 1966) \\ 3.Treynor (1965) \\ 4.Jensen (1968 - 1969)}

\section{Metode Analisis Data}

Adapun tahapan analisis data adalah sebagai berikut : 


\section{Menggolongkan reksa dana sebagai Superior atau Inferior? 2. Analisis konsistensi kinerja reksa dana}

Analisis terhadap konsistensi kinerja reksa dana dilakukan dengan beberapa metode sebagai berikut :

1) Metode Probabilita

2) Uji chi squared

\section{Peringkat Reksa Dana}

Reksa dana unggulan adalah reksa dana yang menempati posisi superior minimal pada tiga metode yang digunakan. Setelah mengetahui reksa dana mana yang unggul berdasarkan raw return, Raw return, Sharpe, Treynor, Jensen dan Sortino, Treynor, Jensen dan Sortino dibuat peringkat reksa dana dari yang terbaik sampai yang terburuk.

\section{HASIL DAN PEMBAHASAN}

\section{Menggolongkan reksa dana sebagai superior atau inferior}

Tabel 2. Rekap Kinerja Reksa Dana menurut Raw Return

\begin{tabular}{|c|l|c|c|c|c|c|c|}
\hline No & \multicolumn{1}{|c|}{ Nama Reksa Dana } & 2002 & 2003 & 2004 & 2005 & 2006 & 2007 \\
\hline 1 & IHSG & 0.0067 & 0.0415 & 0.0312 & 0.0126 & 0.0374 & 0.0356 \\
\hline 2 & ABN AMRO IND. DANA SAHAM & 0.0112 & 0.0334 & 0.0300 & 0.0001 & 0.0365 & 0.0330 \\
\hline 3 & BAHANA DANA PRIMA & 0.0131 & 0.0460 & 0.0332 & 0.0085 & 0.0387 & 0.0436 \\
\hline 4 & BIG NUSANTARA & 0.0015 & 0.0252 & 0.0022 & -0.0057 & -0.0092 & 0.0234 \\
\hline 5 & BIG PALAPA & 0.0047 & 0.0145 & 0.0128 & 0.0002 & 0.0217 & 0.0240 \\
\hline 6 & BNI BERKEMBANG & 0.0010 & 0.0309 & 0.0212 & 0.0078 & 0.0336 & 0.0185 \\
\hline 7 & DANAREKSA MAWAR & 0.0147 & 0.0397 & 0.0308 & 0.0138 & 0.0356 & 0.0404 \\
\hline 8 & FORTIS EKUITAS & 0.0162 & 0.0393 & 0.0353 & 0.0243 & 0.0402 & 0.0521 \\
\hline 9 & FORTIS PESONA & 0.0157 & 0.0422 & 0.0409 & 0.0173 & 0.0452 & 0.0434 \\
\hline 10 & MASTER DINAMIS & 0.0006 & 0.0234 & 0.0235 & 0.0187 & 0.0323 & 0.0375 \\
\hline 11 & NIKKO SAHAM NUSANTARA & 0.0063 & 0.0177 & 0.0281 & 0.0030 & 0.0289 & 0.0104 \\
\hline 12 & PANIN DANA MAKSIMA & 0.0132 & 0.0428 & 0.0259 & 0.0199 & 0.0454 & 0.0238 \\
\hline 13 & PHINISI DANA SAHAM & 0.0121 & 0.0462 & 0.0324 & 0.0200 & 0.0399 & 0.0398 \\
\hline 14 & RENCANA CERDAS & 0.0134 & 0.0435 & 0.0387 & 0.0215 & 0.0387 & 0.0333 \\
\hline 15 & SCHRODER PRESTASI PLUS & 0.0236 & 0.0496 & 0.0404 & 0.0141 & 0.0386 & 0.0378 \\
\hline 16 & SIDANA SAHAM & 0.0117 & 0.0391 & 0.0434 & 0.0203 & 0.0359 & 0.0338 \\
\hline 17 & TRIM KAPITAL & -0.0107 & 0.0264 & 0.0377 & 0.0264 & 0.0473 & 0.0441 \\
\hline
\end{tabular}




\begin{tabular}{|c|l|cccccc|}
\hline No & \multicolumn{1}{|c|}{ Nama Reksa Dana } & 2002 & 2003 & 2004 & 2005 & 2006 & 2007 \\
\hline 1 & ABN AMRO IND. DANA SAHAM & $\mathrm{S}$ & $\mathrm{I}$ & $\mathrm{S}$ & $\mathrm{I}$ & $\mathrm{S}$ & $\mathrm{I}$ \\
2 & BAHANA DANA PRIMA & $\mathrm{S}$ & $\mathrm{S}$ & $\mathrm{S}$ & $\mathrm{I}$ & $\mathrm{S}$ & $\mathrm{S}$ \\
3 & BIG NUSANTARA & $\mathrm{I}$ & $\mathrm{I}$ & $\mathrm{I}$ & $\mathrm{I}$ & $\mathrm{I}$ & $\mathrm{I}$ \\
4 & BIG PALAPA & $\mathrm{I}$ & $\mathrm{I}$ & $\mathrm{I}$ & $\mathrm{I}$ & $\mathrm{I}$ & $\mathrm{I}$ \\
5 & BNI BERKEMBANG & $\mathrm{I}$ & $\mathrm{I}$ & $\mathrm{I}$ & $\mathrm{I}$ & $\mathrm{I}$ & $\mathrm{I}$ \\
6 & DANAREKSA MAWAR & $\mathrm{S}$ & $\mathrm{S}$ & $\mathrm{S}$ & $\mathrm{S}$ & $\mathrm{S}$ & $\mathrm{S}$ \\
8 & FORTIS EKUITAS & SORTIS PESONA & $\mathrm{S}$ & $\mathrm{S}$ & $\mathrm{S}$ & $\mathrm{S}$ & $\mathrm{S}$ \\
9 & MASTER DINAMIS & $\mathrm{S}$ & $\mathrm{S}$ & $\mathrm{S}$ & $\mathrm{S}$ & $\mathrm{S}$ & $\mathrm{S}$ \\
10 & NIKKO SAHAM NUSANTARA & $\mathrm{I}$ & $\mathrm{I}$ & $\mathrm{I}$ & $\mathrm{I}$ & $\mathrm{I}$ & $\mathrm{I}$ \\
11 & PANIN DANA MAKSIMA & $\mathrm{S}$ & $\mathrm{S}$ & $\mathrm{I}$ & $\mathrm{S}$ & $\mathrm{S}$ & $\mathrm{I}$ \\
12 & PHINISI DANA SAHAM & $\mathrm{S}$ & $\mathrm{S}$ & $\mathrm{S}$ & $\mathrm{S}$ & $\mathrm{S}$ & $\mathrm{S}$ \\
13 & RENCANA CERDAS & $\mathrm{S}$ & $\mathrm{S}$ & $\mathrm{S}$ & $\mathrm{S}$ & $\mathrm{S}$ & $\mathrm{I}$ \\
14 & SCHRODER PRESTASI PLUS & $\mathrm{S}$ & $\mathrm{S}$ & $\mathrm{S}$ & $\mathrm{S}$ & $\mathrm{S}$ & $\mathrm{S}$ \\
15 & SIDANA SAHAM & $\mathrm{S}$ & $\mathrm{S}$ & $\mathrm{S}$ & $\mathrm{S}$ & $\mathrm{S}$ & $\mathrm{S}$ \\
16 & TRIM KAPITAL & $\mathrm{I}$ & $\mathrm{I}$ & $\mathrm{S}$ & $\mathrm{S}$ & $\mathrm{S}$ & $\mathrm{S}$ \\
\hline
\end{tabular}

Sumber : diolah oleh penulis

Tabel 2. Rekap Kinerja Reksa Dana menurut Sharpe Ratio

\begin{tabular}{|c|l|c|c|c|c|c|c|}
\hline No & \multicolumn{1}{|c|}{ Nama Reksa Dana } & 2002 & 2003 & 2004 & 2005 & 2006 & 2007 \\
\hline 1 & IHSG & -0.0697 & 0.4977 & 0.4438 & 0.1005 & 0.5096 & 0.5183 \\
\hline 2 & ABN AMRO IND. DANA SAHAM & -0.0162 & 0.3954 & 0.4319 & -0.1421 & 0.9565 & 0.4105 \\
\hline 3 & BAHANA DANA PRIMA & 0.0067 & 0.5541 & 0.4341 & 0.0181 & 0.5109 & 0.5152 \\
\hline 4 & BIG NUSANTARA & -0.1659 & 0.2806 & -0.0892 & -0.1641 & -0.3701 & 0.2778 \\
\hline 5 & BIG PALAPA & -0.1558 & 0.1178 & 0.1412 & -0.1617 & 0.3309 & 0.4126 \\
\hline 6 & BNI BERKEMBANG & -0.1497 & 0.3437 & 0.2470 & 0.0037 & 0.5222 & 0.2202 \\
\hline 7 & DANAREKSA MAWAR & 0.0332 & 0.5095 & 0.4265 & 0.1515 & 0.5046 & 0.5076 \\
\hline 8 & FORTIS EKUITAS & 0.0356 & 0.4034 & 0.4143 & 0.3701 & 0.6145 & 0.7367 \\
\hline 9 & FORTIS PESONA & 0.0400 & 0.5182 & 0.5989 & 0.2036 & 0.6669 & 0.5263 \\
\hline 10 & MASTER DINAMIS & -0.1395 & 0.2398 & 0.2741 & 0.2725 & 0.4802 & 0.4896 \\
\hline 11 & NIKKO SAHAM NUSANTARA & -0.0785 & 0.1587 & 0.4456 & -0.1071 & 0.3347 & 0.0713 \\
\hline 12 & PANIN DANA MAKSIMA & 0.0069 & 0.5725 & 0.3244 & 0.2534 & 0.8266 & 0.3809 \\
\hline 13 & PHINISI DANA SAHAM & -0.0053 & 0.5067 & 0.4211 & 0.2586 & 0.6218 & 0.4960 \\
\hline 14 & RENCANA CERDAS & 0.0102 & 0.5518 & 0.6052 & 0.2938 & 0.5355 & 0.4332 \\
\hline
\end{tabular}




\begin{tabular}{|l|l|c|c|c|c|c|c|}
15 & SCHRODER PRESTASI PLUS & 0.1176 & 0.5666 & 0.6512 & 0.1328 & 0.5652 & 0.5163 \\
\hline 16 & SIDANA SAHAM & -0.0115 & 0.4742 & 0.6535 & 0.2608 & 0.4608 & 0.4355 \\
\hline 17 & TRIM KAPITAL & -0.3710 & 0.3487 & 0.4387 & 0.3851 & 0.7165 & 0.5027 \\
\hline
\end{tabular}

\begin{tabular}{|c|l|cccccc|}
\hline No & \multicolumn{1}{|c|}{ Nama Reksa Dana } & 2002 & 2003 & 2004 & 2005 & 2006 & 2007 \\
\hline 1 & ABN AMRO IND. DANA SAHAM & I & I & S & I & S & I \\
2 & BAHANA DANA PRIMA & S & S & S & I & I & S \\
3 & BIG NUSANTARA & I & I & I & I & I & I \\
4 & BIG PALAPA & I & I & I & I & I & I \\
5 & BNI BERKEMBANG & I & I & I & I & S & I \\
6 & DANAREKSA MAWAR & S & S & S & S & I & S \\
7 & FORTIS EKUITAS & S & I & S & S & S & S \\
8 & FORTIS PESONA & S & S & S & S & S & S \\
9 & MASTER DINAMIS & I & I & I & S & I & S \\
10 & NIKKO SAHAM NUSANTARA & I & I & S & I & I & I \\
11 & PANIN DANA MAKSIMA & S & S & I & S & S & I \\
12 & PHINISI DANA SAHAM & I & S & S & S & S & S \\
13 & RENCANA CERDAS & S & S & S & S & S & I \\
14 & SCHRODER PRESTASI PLUS & S & S & S & S & S & S \\
15 & SIDANA SAHAM & I & S & S & S & I & S \\
16 & TRIM KAPITAL & I & S & S & S & S \\
\hline & & & & & Sumber : diolah oleh penulis
\end{tabular}

Tabel 3. Rekap Kinerja Reksa Dana menurut Jensen alpha Ratio

\begin{tabular}{|c|l|c|c|c|c|c|c|}
\hline No & \multicolumn{1}{|c|}{ Nama Reksa Dana } & 2002 & 2003 & 2004 & 2005 & 2006 & 2007 \\
\hline 1 & IHSG & -0.0005 & 0.0027 & 0.0021 & 0.0004 & 0.0023 & 0.0023 \\
\hline 2 & ABN AMRO IND. DANA SAHAM & 0.0040 & -0.0034 & 0.0016 & -0.0121 & 0.0199 & -0.0032 \\
\hline 3 & BAHANA DANA PRIMA & 0.0054 & 0.0073 & 0.0023 & -0.0469 & 0.0043 & 0.0199 \\
\hline 4 & BIG NUSANTARA & -0.0069 & -0.0087 & -0.0206 & -0.0520 & -0.0481 & 0.0055 \\
\hline 5 & BIG PALAPA & -0.0050 & -0.0114 & -0.0069 & -0.0105 & -0.0003 & 0.0005 \\
\hline 6 & BNI BERKEMBANG & -0.0070 & -0.0021 & -0.0054 & -0.0051 & 0.0051 & -0.0124 \\
\hline 7 & DANAREKSA MAWAR & 0.0062 & 0.0045 & 0.0019 & -0.0320 & 0.0033 & 0.0039 \\
\hline 8 & FORTIS EKUITAS & 0.0101 & -0.0031 & 0.0011 & 0.0127 & 0.0079 & 0.0168 \\
\hline 9 & FORTIS PESONA & 0.0081 & 0.0053 & 0.0113 & 0.0054 & 0.0119 & 0.0044 \\
\hline 10 & MASTER DINAMIS & -0.0066 & -0.0124 & 0.0056 & -0.0035 & 0.0012 & 0.0023 \\
\hline
\end{tabular}




\begin{tabular}{|c|l|r|r|r|r|r|r|}
11 & NIKKO SAHAM NUSANTARA & -0.0015 & -0.0132 & 0.0048 & -0.0079 & -0.0021 & -0.0157 \\
\hline 12 & PANIN DANA MAKSIMA & 0.0054 & 0.0086 & 0.0036 & 0.0083 & 0.0162 & 0.0011 \\
\hline 13 & PHINISI DANA SAHAM & 0.0058 & 0.0041 & 0.0014 & 0.0080 & 0.0083 & 0.0024 \\
\hline 14 & RENCANA CERDAS & 0.0062 & 0.0070 & 0.0119 & 0.0098 & 0.0051 & -0.0013 \\
\hline 15 & SCHRODER PRESTASI PLUS & 0.0165 & 0.0091 & 0.0137 & 0.0021 & 0.0052 & 0.0033 \\
\hline 16 & TRIM KAPITAL & -0.0198 & 0.0008 & 0.0108 & 0.0145 & 0.0145 & 0.0029 \\
\hline 17 & SIDANA SAHAM & 0.0042 & 0.0015 & 0.0147 & 0.0083 & 0.0042 & -0.0020 \\
\hline
\end{tabular}

(Continued)

\begin{tabular}{|c|l|cccccc|}
\hline No & \multicolumn{1}{|c|}{ Nama Reksa Dana } & 2002 & 2003 & 2004 & 2005 & 2006 & 2007 \\
\hline 1 & ABN AMRO IND. DANA SAHAM & S & I & I & I & S & I \\
2 & BAHANA DANA PRIMA & S & S & I & I & S & S \\
3 & BIG NUSANTARA & I & I & I & I & I & S \\
4 & BIG PALAPA & I & I & I & I & I & I \\
5 & BNI BERKEMBANG & I & I & I & I & S & I \\
6 & DANAREKSA MAWAR & S & S & I & I & I & S \\
7 & FORTIS EKUITAS & S & I & I & S & S & S \\
8 & FORTIS PESONA & S & S & S & S & S & S \\
9 & MASTER DINAMIS & I & I & S & I & I & S \\
10 & NIKKO SAHAM NUSANTARA & I & I & S & I & I & I \\
11 & PANIN DANA MAKSIMA & S & S & S & S & S & I \\
12 & PHINISI DANA SAHAM & S & S & I & S & S & S \\
13 & RENCANA CERDAS & S & S & S & S & S & I \\
14 & SCHRODER PRESTASI PLUS & S & S & S & S & S & S \\
15 & SIDANA SAHAM & S & S & S & S & S & I \\
16 & TRIM KAPITAL & I & S & S & S & S & S \\
\hline
\end{tabular}

Sumber : diolah oleh penulis

Tabel 4. Rekap Kinerja Reksa Dana menurut Sortino Ratio

\begin{tabular}{|c|l|c|c|c|c|c|c|}
\hline No & \multicolumn{1}{|c|}{ Nama Reksa Dana } & 2002 & 2003 & 2004 & 2005 & 2006 & 2007 \\
\hline 1 & IHSG & -0.1069 & 0.7122 & 0.6548 & 0.1196 & 0.6252 & 0.7246 \\
\hline 2 & ABN AMRO IND. DANA SAHAM & -0.0264 & 0.5732 & 0.6654 & -0.1737 & 1.3131 & 0.5819 \\
\hline 3 & BAHANA DANA PRIMA & 0.0108 & 0.7736 & 0.6088 & 0.0227 & 0.6856 & 0.7681 \\
\hline 4 & BIG NUSANTARA & -0.2560 & 0.4184 & -0.1171 & -0.2346 & -0.4521 & 0.3809 \\
\hline 5 & BIG PALAPA & -0.2453 & 0.1747 & 0.1883 & -0.2037 & 0.4019 & 0.5752 \\
\hline 6 & BNI BERKEMBANG & -0.2102 & 0.4960 & 0.3313 & 0.0047 & 0.6498 & 0.3145 \\
\hline 7 & DANAREKSA MAWAR & 0.0505 & 0.7311 & 0.6399 & 0.1834 & 0.6910 & 0.7489 \\
\hline
\end{tabular}




\begin{tabular}{|c|l|c|c|c|c|c|c|}
\hline 8 & FORTIS EKUITAS & 0.0555 & 0.6118 & 0.5958 & 0.4541 & 0.7520 & 1.0457 \\
\hline 9 & FORTIS PESONA & 0.0654 & 0.7909 & 0.8628 & 0.2468 & 0.8662 & 0.7672 \\
\hline 10 & MASTER DINAMIS & -0.2084 & 0.3568 & 0.4903 & 0.3264 & 0.5785 & 0.7576 \\
\hline 11 & NIKKO SAHAM NUSANTARA & -0.1091 & 0.2027 & 0.7799 & -0.1400 & 0.4392 & 0.0907 \\
\hline 12 & PANIN DANA MAKSIMA & 0.0110 & 0.8414 & 0.4680 & 0.2855 & 0.9713 & 0.4989 \\
\hline 13 & PHINISI DANA SAHAM & -0.0053 & 0.5033 & 0.4213 & 0.2587 & 0.6206 & 0.4948 \\
\hline 14 & RENCANA CERDAS & 0.0158 & 0.7741 & 0.8913 & 0.3562 & 0.6474 & 0.5679 \\
\hline 15 & SCHRODER PRESTASI PLUS & 0.1802 & 0.8423 & 1.0256 & 0.1603 & 0.6947 & 0.7616 \\
\hline 16 & SIDANA SAHAM & -0.0175 & 0.7211 & 0.9655 & 0.3211 & 0.6195 & 0.6175 \\
\hline 17 & TRIM KAPITAL & -0.5706 & 0.5005 & 0.7719 & 0.4721 & 0.9720 & 0.6774 \\
\hline
\end{tabular}

\begin{tabular}{|c|c|c|c|c|c|c|c|}
\hline No & Nama Reksa Dana & 2002 & 2003 & 2004 & 2005 & 2006 & 2007 \\
\hline 1 & ABN AMRO IND. DANA SAHAM & I & I & $\mathrm{S}$ & I & $\mathrm{S}$ & I \\
\hline 2 & BAHANA DANA PRIMA & $\mathrm{S}$ & $\mathrm{S}$ & $\mathrm{S}$ & I & $\mathrm{S}$ & $\mathrm{S}$ \\
\hline 3 & BIG NUSANTARA & I & I & I & $\mathrm{I}$ & I & I \\
\hline 4 & BIG PALAPA & I & I & I & I & I & I \\
\hline 5 & BNI BERKEMBANG & I & I & I & I & I & I \\
\hline 6 & DANAREKSA MAWAR & $\mathrm{S}$ & $\mathrm{S}$ & $\mathrm{S}$ & $\mathrm{S}$ & $\mathrm{S}$ & $\mathrm{S}$ \\
\hline 7 & FORTIS EKUITAS & $\mathrm{S}$ & $\mathrm{S}$ & I & $\mathrm{S}$ & $\mathrm{S}$ & $\mathrm{S}$ \\
\hline 8 & FORTIS PESONA & $\mathrm{S}$ & $\mathrm{S}$ & $\mathrm{S}$ & $\mathrm{S}$ & $\mathrm{S}$ & $\mathrm{S}$ \\
\hline 9 & MASTER DINAMIS & I & I & I & $\mathrm{S}$ & I & $\mathrm{S}$ \\
\hline 10 & NIKKO SAHAM NUSANTARA & I & I & $\mathrm{S}$ & I & I & I \\
\hline 11 & PANIN DANA MAKSIMA & $\mathrm{S}$ & $\mathrm{S}$ & I & $\mathrm{S}$ & $\mathrm{S}$ & I \\
\hline 12 & PHINISI DANA SAHAM & I & I & I & $\mathrm{S}$ & I & I \\
\hline 13 & RENCANA CERDAS & S & $\mathrm{S}$ & S & S & I & I \\
\hline 14 & SCHRODER PRESTASI PLUS & $\mathrm{S}$ & $\mathrm{S}$ & S & $\mathrm{S}$ & $\mathrm{S}$ & $\mathrm{S}$ \\
\hline 15 & SIDANA SAHAM & I & $\mathrm{S}$ & $\mathrm{S}$ & $\mathrm{S}$ & I & $\mathrm{S}$ \\
\hline 16 & TRIM KAPITAL & I & I & $\mathrm{S}$ & $\mathrm{S}$ & $\mathrm{S}$ & $\mathrm{S}$ \\
\hline
\end{tabular}

\section{Analisis Konsistensi Kinerja Reksa Dana}

Setelah kita memposisikan semua reksa dana sebagai superior atau inferior kita akan melakukan uji konsistensi. Berdasarkan posisi reksa dana tersebut selama enam tahun dapat diketahui apakah konsistensi kinerja terjadi.

Uji konsistensi dilakukan dengan menggunakan dua metode, yaitu metode probabilita dan uji chi squared. 
Dengan uji konsistensi ini dapat diketahui apakah terdapat konsistensi pada kinerja reksa dana dari tahun ke tahun. Jika terdapat konsistensi, maka kinerja historis dapat dijadikan salah satu dasar pertimbangan bagi investor untuk memilih reksa dana.

\section{Metode Probabilita}

Metode probabilita merupakan perhitungan sederhana untuk mengetahui seberapa besar konsistensi yang terjadi dari tahun ke tahun.

Dengan metode ini dapat diketahui seberapa besar reksa dana yang superior akan tetap unggul di tahun berikutnya. Ataukah akan terjadi inkonsistensi, artinya reksa dana tersebut tidak cukup tangguh untuk mempertahankan prestasinya.

\section{Raw Return}

Tabel 5. Probabilita Konsistensi menurut Raw Return

\begin{tabular}{|c|c|c|c|}
\hline & \multicolumn{2}{|c|}{ TAHUN 2} \\
\hline & & $\mathrm{S}$ & I \\
\hline \multirow[t]{4}{*}{$\begin{array}{c}\text { TAHUN } \\
1\end{array}$} & $\mathrm{~S}$ & 9 & 1 \\
\hline & & $56.25 \%$ & $6.25 \%$ \\
\hline & I & 0 & 6 \\
\hline & & $0.00 \%$ & $37.50 \%$ \\
\hline
\end{tabular}

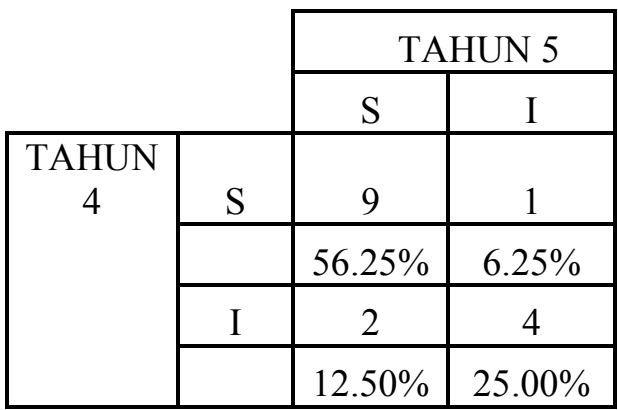

\begin{tabular}{|c|c|c|c|}
\cline { 3 - 4 } \multicolumn{2}{c|}{} & \multicolumn{2}{c|}{ TAHUN 3 } \\
\cline { 3 - 4 } \multicolumn{1}{c|}{$\begin{array}{c}\text { TAHUN } \\
2\end{array}$} & $\mathrm{~S}$ & 8 & 0 \\
\cline { 2 - 4 } & & $50.00 \%$ & $0.00 \%$ \\
\cline { 2 - 4 } & $\mathrm{I}$ & 2 & 6 \\
\cline { 2 - 4 } & & $12.50 \%$ & $37.50 \%$ \\
\hline
\end{tabular}

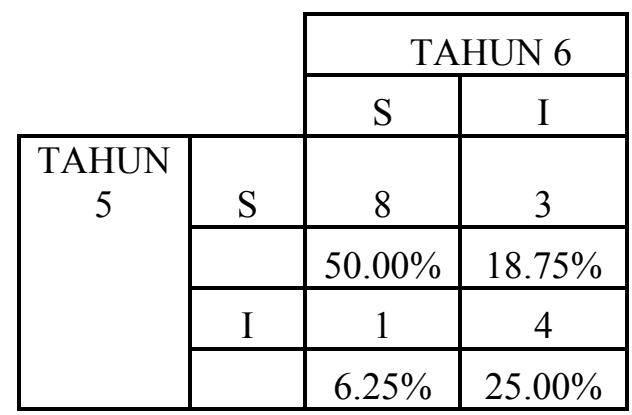

\begin{tabular}{|c|c|c|c|}
\hline & \multicolumn{2}{|c|}{ TAHUN 4} \\
\hline & & $\mathrm{S}$ & I \\
\hline \multirow[t]{4}{*}{$\begin{array}{c}\text { TAHUN } \\
3\end{array}$} & $\mathrm{~S}$ & 8 & 2 \\
\hline & & $50.00 \%$ & $12.50 \%$ \\
\hline & I & 2 & 4 \\
\hline & & $12.50 \%$ & $25.00 \%$ \\
\hline
\end{tabular}

\begin{tabular}{|c|c|c|c|}
\hline \multicolumn{2}{|c|}{ GABUNGAN } & \multicolumn{2}{|c|}{ TAHUN $\mathrm{t}+1$} \\
\hline & & $\mathrm{S}$ & I \\
\hline \multirow[t]{4}{*}{$\begin{array}{c}\text { TAHUN } \\
\mathrm{t}\end{array}$} & $\mathrm{S}$ & 42 & 7 \\
\hline & & $52.50 \%$ & $8.75 \%$ \\
\hline & I & 7 & 24 \\
\hline & & $8.75 \%$ & $30.00 \%$ \\
\hline
\end{tabular}


Tabel 6. Probabilita Konsistensi SS dan II menurut Raw Return

\begin{tabular}{|c|c|c|c|c|c|c|}
\hline Tahun & $\mathbf{n}(\mathbf{S S})$ & $\mathrm{n}(\mathrm{SI})$ & $\mathrm{n}(\mathrm{IS})$ & $\mathbf{n}(\mathbf{I I})$ & $\mathrm{n}$ & $\begin{array}{c}\text { Probabilita } \\
\text { Konsistensi }\end{array}$ \\
\hline $1-2$ & $\mathbf{9}$ & 1 & 0 & $\mathbf{6}$ & 16 & $93.75 \%$ \\
$2-3$ & $\mathbf{8}$ & 0 & 2 & $\mathbf{6}$ & 16 & $87.50 \%$ \\
$3-4$ & $\mathbf{8}$ & 2 & 2 & $\mathbf{4}$ & 16 & $75.00 \%$ \\
$4-5$ & $\mathbf{9}$ & 1 & 2 & $\mathbf{4}$ & 16 & $81.25 \%$ \\
$5-6$ & $\mathbf{8}$ & 3 & 1 & $\mathbf{4}$ & 16 & $75.00 \%$ \\
$1-6$ & $\mathbf{4 2}$ & 7 & 7 & $\mathbf{2 4}$ & 80 & $82.50 \%$ \\
\end{tabular}

Probabilita konsistensi menurut raw return atas kemungkinan SS dan II pada setiap tahun menunjukkan angka yang signifikan. Angka berkisar antara $75.00 \% \mathrm{~s} / \mathrm{d}$ 93.75\% dengan probabilita konsistensi gabungan selama enam tahun sebesar $82.50 \%$.

Walaupun dengan probabilita konsistensi selama enam tahun yang significan sebesar 82.5 , terjadi tren penurunan presentase probabilita konsistensi pada tahun pertama ke tahun keempat, dari $93.75 \%$ menjadi $75 \%$. Meskipun terjadi penurunan persentase probabilita konsistensi, hal tersebut tidak berpengaruh besar karena persentase probabilita konsistensi masih signifikan yaitu diatas $75 \%$.

Dalam enam tahun periode penelitian terbukti sebanyak 42 reksa dana yang konsisten menunjukkan kinerja superior. Konsistensi juga terjadi pada 24 reksa dana tetapi dengan kinerja yang inferior. Dengan 68 reksa dana yang konsistensi maka diperoleh probabilita konsistensi gabungan selama enam tahun sebesar $82.50 \%$. Jadi dapat ditarik kesimpulkan bahwa terdapat konsistensi yang cukup tinggi antara kinerja reksa dana masa lalu dengan masa yang akan datang berdasarkan raw return. Ini berarti investor dapat menggunakan raw return sebagai salah satu acuan untuk memilih suatu reksa dana.

\section{Sharpe Ratio}

Tabel 7. Probabilita Konsistensi menurut Sharpe ratio

\begin{tabular}{|c|c|c|c|}
\hline & & \multicolumn{2}{|c|}{ TAHUN 2} \\
\hline & & $S$ & I \\
\hline \multirow{5}{*}{$\begin{array}{c}\text { TAHUN } \\
1\end{array}$} & & & \\
\hline & $\mathrm{S}$ & 6 & 1 \\
\hline & & $37.50 \%$ & $6.25 \%$ \\
\hline & I & 2 & 7 \\
\hline & & $12.50 \%$ & $43.75 \%$ \\
\hline & & \multicolumn{2}{|c|}{ TAHUN 3} \\
\hline
\end{tabular}

\begin{tabular}{|c|c|c|c|}
\cline { 3 - 4 } \multicolumn{2}{c|}{} & \multicolumn{2}{c|}{ TAHUN 5 } \\
\cline { 3 - 4 } \multicolumn{2}{c|}{$\begin{array}{c}\text { TAHUN } \\
4\end{array}$} & $\mathrm{~S}$ & $\mathrm{I}$ \\
\cline { 2 - 4 } & & 7 & 3 \\
\cline { 2 - 4 } & & $43.75 \%$ & $18.75 \%$ \\
\cline { 2 - 4 } & $\mathrm{I}$ & 2 & 4 \\
\cline { 2 - 4 } & & $12.50 \%$ & $25.00 \%$ \\
& \multicolumn{3}{|c|}{ TAHUN 6 } \\
\cline { 2 - 2 }
\end{tabular}




\begin{tabular}{|c|c|c|c|}
\multicolumn{2}{c|}{} & $\mathrm{S}$ & $\mathrm{I}$ \\
\hline $\begin{array}{c}\text { TAHUN } \\
2\end{array}$ & $\mathrm{~S}$ & 6 & 1 \\
\cline { 2 - 4 } & & $37.50 \%$ & $6.25 \%$ \\
\cline { 2 - 4 } & $\mathrm{I}$ & 5 & 4 \\
\cline { 2 - 4 } & & $31.25 \%$ & $25.00 \%$ \\
\hline
\end{tabular}

\begin{tabular}{|c|c|c|c|}
\cline { 3 - 4 } \multicolumn{2}{c|}{} & \multicolumn{2}{c|}{ TAHUN 4 } \\
\cline { 3 - 4 } \multicolumn{2}{c|}{} & $\mathrm{S}$ & $\mathrm{I}$ \\
\hline \multirow{3}{*}{$\begin{array}{c}\text { TAHUN } \\
3\end{array}$} & $\mathrm{~S}$ & 8 & 3 \\
\cline { 2 - 4 } & & $50.00 \%$ & $18.75 \%$ \\
\cline { 2 - 4 } & $\mathrm{I}$ & 2 & 3 \\
\cline { 2 - 4 } & & $12.50 \%$ & $18.75 \%$ \\
\hline
\end{tabular}
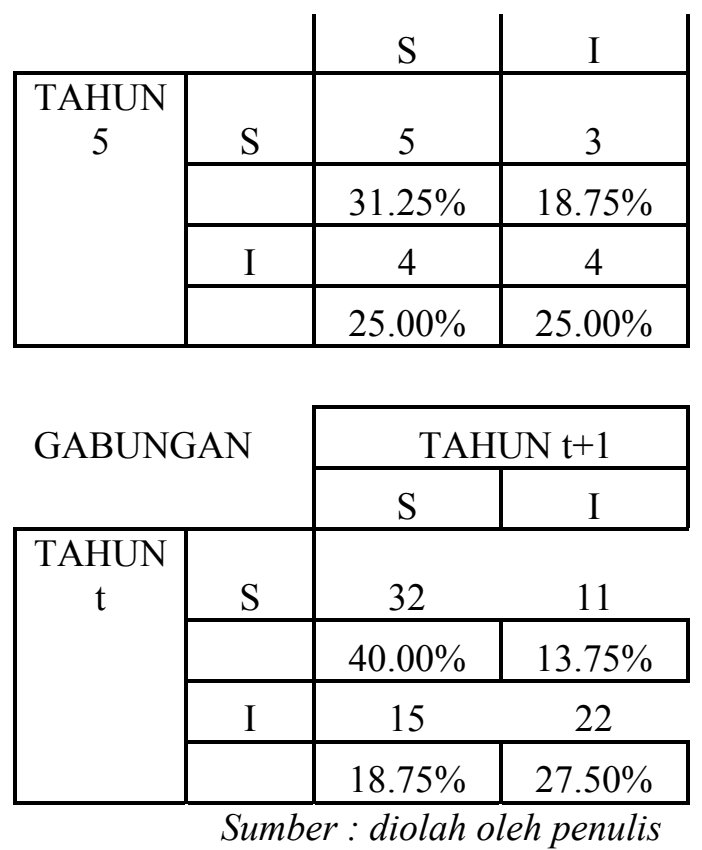

Tabel 8. Probabilita Konsistensi SS dan II menurut Sharpe ratio

\begin{tabular}{|c|c|c|c|c|c|c|}
\hline Tahun & $\mathbf{n ( S S )}$ & $\mathrm{n}(\mathrm{SI})$ & $\mathrm{n}(\mathrm{IS})$ & $\mathbf{n}(\mathbf{I I})$ & $\mathrm{n}$ & $\begin{array}{c}\text { Probabilita } \\
\text { Konsistensi }\end{array}$ \\
\hline $1-2$ & $\mathbf{6}$ & $\mathbf{1}$ & 2 & 7 & 16 & $81.25 \%$ \\
$2-3$ & $\mathbf{6}$ & $\mathbf{1}$ & 5 & 4 & 16 & $62.50 \%$ \\
$3-4$ & $\mathbf{8}$ & $\mathbf{3}$ & 2 & 3 & 16 & $68.75 \%$ \\
$4-5$ & $\mathbf{7}$ & $\mathbf{3}$ & 2 & 4 & 16 & $68.75 \%$ \\
$5-6$ & $\mathbf{5}$ & $\mathbf{3}$ & 4 & 4 & 16 & $56.25 \%$ \\
$1-6$ & $\mathbf{3 2}$ & 11 & 15 & $\mathbf{2 2}$ & 80 & $67.50 \%$ \\
\hline
\end{tabular}

Probabilita konsistensi menurut Sharpe ratio secara keseluruhan menunjukkan persentase yang lebih kecil bila dibandingkan dengan raw return, yaitu sebesar $67.50 \%$.

Angka konsistensi menurut Sharpe ratio mengalami perubahan dari tahun ke tahun. Konsistensi terendah sebesar $56.25 \%$ terjadi pada tahun keenam. Hal ini disebabkan karena tiga reksa dana tidak dapat mempertahankan prestasinya sebagai superior.

Pada tahun kedua, Sharpe ratio berhasil mencapai angka konsistensi tertinggi sebesar $81.25 \%$. Konsistensi sebesar $81.25 \%$ ini diperoleh karena 6 reksa dana konsisten dengan kinerjanya yang superior dan 7 reksa dana konsisten dengan kinerja inferior.

Pada tahun ketiga, angka konsistensi mengalami penurunan yang cukup drastis sebesar $18.75 \%$ ke posisi $62.50 \%$. Pada tahun ke empat dan kelima, persentase probabilita konsistensi berada di $68.75 \%$, terjadi peningkatan dibandingkan tahun sebelumnya Angka ini tidak bertahan lama, satu tahun kemudian, pada tahun keenam persentase probabilita konsistensi berada di angka 56.25\%. 
Di bandingkan dengan raw return, persentase probabilita konsistensi Sharpe ratio lebih rendah. Walaupun demikian secara keseluruhan dapat dikatakan bahwa terdapat konsistensi berdasarkan Sharpe ratio.

\section{Treynor Ratio}

Tabel 9. Probabilita Konsistensi menurut Treynor ratio

\begin{tabular}{|c|c|c|c|}
\cline { 3 - 4 } \multicolumn{2}{c|}{} & \multicolumn{2}{c|}{ TAHUN 2 } \\
\cline { 3 - 4 } \multicolumn{2}{c|}{} & S & I \\
\hline \multirow{3}{*}{$\begin{array}{c}\text { TAHUN } \\
1\end{array}$} & S & 6 & 1 \\
\cline { 2 - 4 } & & $37.50 \%$ & $6.25 \%$ \\
\cline { 2 - 4 } & $\mathrm{I}$ & 2 & 7 \\
\cline { 2 - 4 } & & $12.50 \%$ & $43.75 \%$ \\
\hline
\end{tabular}

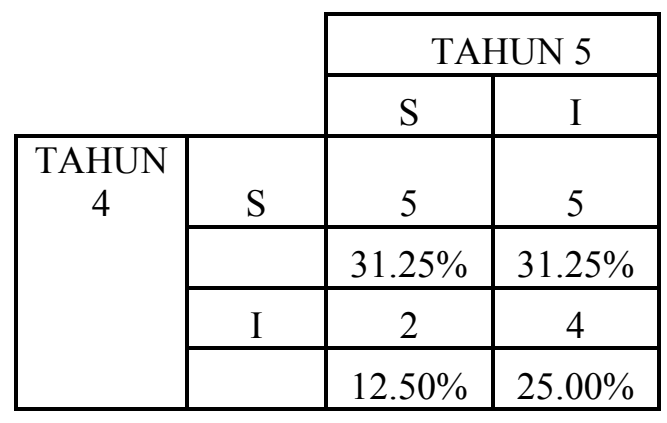

\begin{tabular}{|c|c|c|c|}
\hline & \multicolumn{2}{|c|}{ TAHUN 3} \\
\hline & & $\mathrm{S}$ & I \\
\hline \multirow[t]{4}{*}{$\begin{array}{c}\text { TAHUN } \\
2\end{array}$} & $\mathrm{~S}$ & 4 & 4 \\
\hline & & $25.00 \%$ & $25.00 \%$ \\
\hline & I & 3 & 5 \\
\hline & & $18.75 \%$ & $31.25 \%$ \\
\hline
\end{tabular}

\begin{tabular}{|c|c|c|c|}
\cline { 3 - 4 } \multicolumn{2}{c|}{} & \multicolumn{2}{c|}{ TAHUN 6 } \\
\cline { 3 - 4 } \multicolumn{2}{c|}{} & S & I \\
\hline \multirow{4}{*}{$\begin{array}{c}\text { TAHUN } \\
5\end{array}$} & S & 5 & 1 \\
\cline { 2 - 4 } & & $31.25 \%$ & $6.25 \%$ \\
\cline { 2 - 4 } & $\mathrm{I}$ & 5 & 5 \\
\cline { 2 - 4 } & & $31.25 \%$ & $31.25 \%$ \\
\hline
\end{tabular}

\begin{tabular}{|c|c|c|c|}
\cline { 3 - 4 } \multicolumn{2}{c|}{} & \multicolumn{2}{c|}{ TAHUN 4} \\
\cline { 3 - 4 } \multicolumn{2}{c|}{} & S & I \\
\hline \multirow{3}{*}{$\begin{array}{c}\text { TAHUN } \\
\text { 1 }\end{array}$} & $\mathrm{S}$ & 6 & 2 \\
\cline { 2 - 4 } & & $37.50 \%$ & $12.50 \%$ \\
\cline { 2 - 4 } & $\mathrm{I}$ & 4 & 4 \\
\cline { 2 - 4 } & & $25.00 \%$ & $25.00 \%$ \\
\hline
\end{tabular}

\begin{tabular}{|c|c|c|c|}
\cline { 3 - 4 } \multicolumn{2}{c|}{ GABUNGAN } & \multicolumn{2}{c|}{ TAHUN $\mathrm{t}+1$} \\
\cline { 3 - 4 } \multicolumn{1}{c|}{$\begin{array}{c}\text { TAHUN } \\
\mathrm{t}\end{array}$} & $\mathrm{S}$ & 26 & $\mathrm{I}$ \\
\cline { 2 - 4 } & & $32.50 \%$ & $16.25 \%$ \\
\cline { 2 - 4 } & $\mathrm{I}$ & 16 & 25 \\
\cline { 2 - 4 } & & $20.00 \%$ & $31.25 \%$ \\
\hline \multicolumn{3}{|c|}{ Sumber : diolah oleh penulis }
\end{tabular}

Tabel 10. Probabilita Konsistensi SS dan II menurut Treynor ratio

\begin{tabular}{|c|c|c|c|c|c|c|}
\hline Tahun & $\mathbf{n}(\mathbf{S S})$ & $\mathrm{n}(\mathrm{SI})$ & $\mathrm{n}(\mathrm{IS})$ & $\mathbf{n}(\mathbf{I I})$ & $\mathrm{n}$ & $\begin{array}{c}\text { Probabilita } \\
\text { Konsistensi }\end{array}$ \\
\hline $1-2$ & $\mathbf{6}$ & $\mathbf{1}$ & 2 & 7 & 16 & $81.25 \%$
\end{tabular}




\begin{tabular}{|c|c|c|c|c|c|c|}
$2-3$ & $\mathbf{4}$ & $\mathbf{4}$ & 3 & 5 & 16 & $56.25 \%$ \\
$3-4$ & $\mathbf{6}$ & $\mathbf{2}$ & 4 & 4 & 16 & $62.50 \%$ \\
$4-5$ & $\mathbf{5}$ & $\mathbf{5}$ & 2 & 4 & 16 & $56.25 \%$ \\
$5-6$ & $\mathbf{5}$ & $\mathbf{1}$ & 5 & 5 & 16 & $62.50 \%$ \\
$1-6$ & $\mathbf{2 6}$ & 13 & 16 & $\mathbf{2 5}$ & 80 & $63.75 \%$
\end{tabular}

Sumber : diolah oleh penulis

Dibandingkan dengan dua metode sebelumnya, Treynor menunjukkan tingkat konsistensi gabungan yang paling kecil. Dengan probabilita konsistensi sebesar $63.75 \%$, angka ini lebih rendah $18.75 \%$ dari raw return dan $3.75 \%$ dari Sharpe ratio.

Tidak seperti Sharpe rasio, fluktuasi konsistensi selalu terjadi dari tahun ke tahun. Persentase probabilita konsistensi tertinggi terjadi pada tahun pertama ke tahun kedua sebesar $81.25 \%$. Dan di tahun selanjutnya persentase probabilita konsistensi berada di angka $56.25 \%$ dan $62.50 \%$.

Probabilita konsistensi berkisar antara $56.25 \%$ s/d 81.25\%. Konsistensi tertinggi terjadi pada tahun kedua, dengan 6 reksa dana yang mempunyai kinerja superior dan 7 reksa dana yang mempunyai kinerja inferior yang secara konsisten .

Dalam enam tahun periode penelitian terdapat 26 reksa dana yang mempunyai kinerja superior dan 25 reksa dana yang menpunyai kinerja inferior secara konsisten. Angka konsistensi sebesar $63.75 \%$ ini merupakan konsistensi gabungan atas reksa dana yang superior dan inferior yang seimbang. Dan terdapat 13 reksa dana saham yang selalu berubah dari superior menjadi inferior dan 16 reksa dana yang berubah dari inferior menjadi superior. Hal ini dapat memberikan informasi bahwa konsitensi reksa dana dengan metode Treynor reksa dana saham di Indonesia pada periode tahun 2002 s/d 2007 cukup fluktuatif. Walaupun demikian secara keseluruhan dapat dikatakan bahwa terdapat konsistensi berdasarkan Treynor ratio.

\section{Jensen Alpha}

Tabel 11. Probabilita Konsistensi menurut Jensen alpha

\begin{tabular}{|c|c|c|c|}
\cline { 3 - 4 } \multicolumn{2}{c|}{} & \multicolumn{2}{c|}{ TAHUN 2 } \\
\cline { 3 - 4 } \multicolumn{2}{c|}{$\begin{array}{c}\text { TAHUN } \\
1\end{array}$} & $\mathrm{~S}$ & $\mathrm{~S}$ \\
\cline { 3 - 4 } & $\mathrm{S}$ & 8 & 2 \\
\cline { 2 - 4 } & & $50.00 \%$ & $12.50 \%$ \\
\cline { 2 - 4 } & $\mathrm{I}$ & 1 & 5 \\
\cline { 2 - 4 } & & $6.25 \%$ & $31.25 \%$ \\
\hline
\end{tabular}
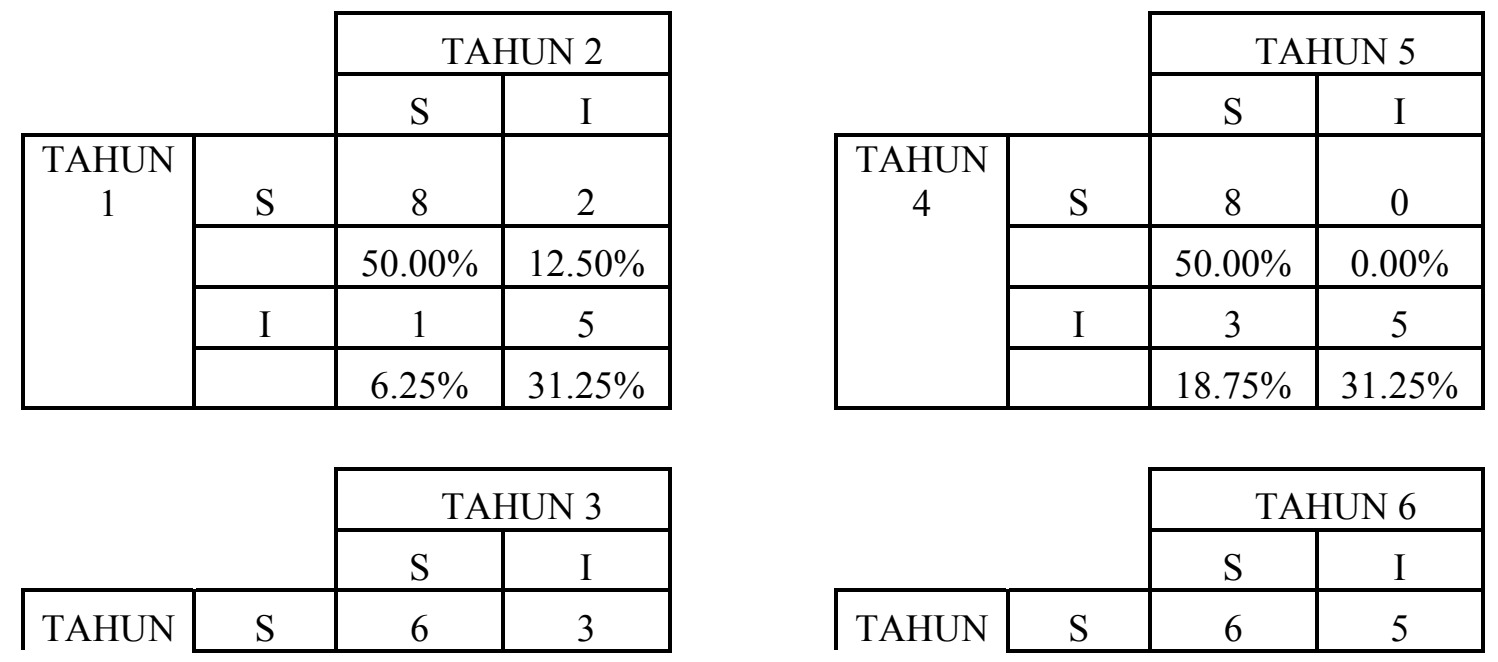


\begin{tabular}{|c|c|c|c|}
\hline 2 & & & \\
\cline { 2 - 4 } & & $37.50 \%$ & $18.75 \%$ \\
\cline { 2 - 4 } & $\mathrm{I}$ & 2 & 5 \\
\cline { 2 - 4 } & & $12.50 \%$ & $31.25 \%$ \\
\hline
\end{tabular}

\begin{tabular}{|c|c|c|c|}
\hline & \multicolumn{2}{|c|}{ TAHUN 4} \\
\hline & & $\mathrm{S}$ & I \\
\hline \multirow[t]{4}{*}{$\begin{array}{c}\text { TAHUN } \\
3\end{array}$} & $\mathrm{~S}$ & 6 & 2 \\
\hline & & $37.50 \%$ & $12.50 \%$ \\
\hline & I & 2 & 6 \\
\hline & & $12.50 \%$ & $37.50 \%$ \\
\hline
\end{tabular}
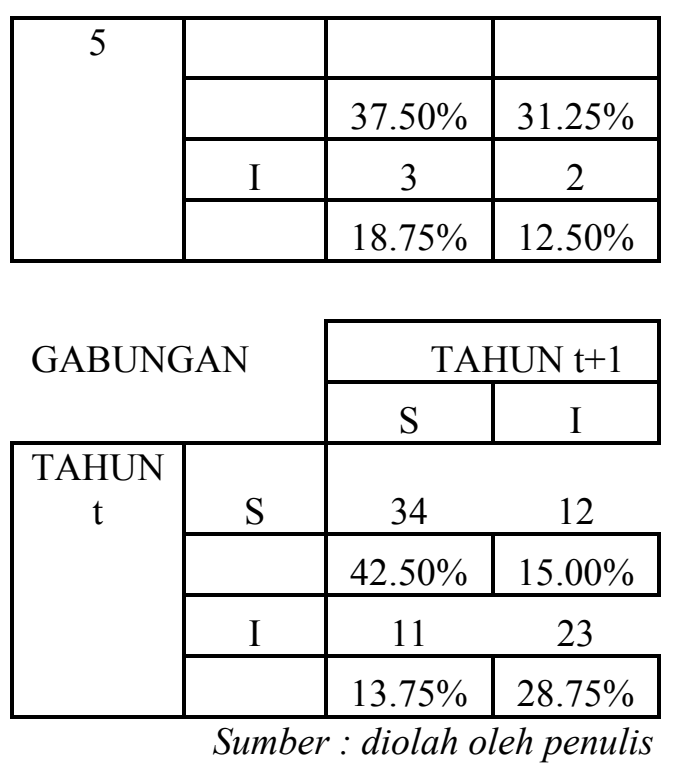

Tabel 12. Probabilita Konsistensi SS dan II menurut Jensen alpha

\begin{tabular}{|c|c|c|c|c|c|c|}
\hline Tahun & $\mathbf{n ( S S )}$ & $\mathrm{n}(\mathrm{SI})$ & $\mathrm{n}(\mathrm{IS})$ & $\mathbf{n}(\mathbf{I I})$ & $\mathrm{n}$ & $\begin{array}{c}\text { Probabilita } \\
\text { Konsistensi }\end{array}$ \\
\hline $1-2$ & $\mathbf{8}$ & $\mathbf{2}$ & 1 & 5 & 16 & $81.25 \%$ \\
$2-3$ & $\mathbf{6}$ & $\mathbf{3}$ & 2 & 5 & 16 & $68.75 \%$ \\
$3-4$ & $\mathbf{6}$ & $\mathbf{2}$ & 2 & 6 & 16 & $75.00 \%$ \\
$4-5$ & $\mathbf{8}$ & $\mathbf{0}$ & 3 & 5 & 16 & $81.25 \%$ \\
$5-6$ & $\mathbf{6}$ & $\mathbf{5}$ & 3 & 2 & 16 & $50.00 \%$ \\
$1-6$ & $\mathbf{3 4}$ & 12 & 11 & $\mathbf{2 3}$ & 80 & $71.25 \%$ \\
\end{tabular}

Probabilita konsistensi menurut Jensen alpha atas kemungkinan SS dan II dari tahun ke tahun menunjukkan angka yang cukup signifikan. Angka berkisar antara $50.00 \% \mathrm{~s} / \mathrm{d}$ $81.25 \%$ dengan probabilita konsistensi gabungan selama enam tahun sebesar $71.25 \%$.

Persentase probabilita konsistensi tertinggi terjadi pada tahun kedua sebesar $81.25 \%$ dan terendah pada tahun keenam sebesar 50\%. Dalam enam tahun penelitian terdapat 34 reksa dana yang superior dan 23 reksa dana yang inferior secara konsisten dari tahun ke tahun. Dan reksa dana superior mendominasi presentase probabilita konsistensi. Dengan demikian dpat ditarik kesimpulan bahwa tingkat konsistensi pada Jensen alpha cukup signifikan dengan angka $71.25 \%$ 


\section{Sortino Ratio}

Tabel 13. Probabilita Konsistensi menurut Sortino ratio

\begin{tabular}{|c|c|c|c|}
\cline { 3 - 4 } \multicolumn{2}{c|}{} & \multicolumn{2}{c|}{ TAHUN 2 } \\
\cline { 3 - 4 } \multicolumn{2}{c|}{} & $\mathrm{S}$ & $\mathrm{I}$ \\
\hline \multirow{3}{*}{$\begin{array}{c}\text { TAHUN } \\
1\end{array}$} & $\mathrm{~S}$ & 7 & 0 \\
\cline { 2 - 4 } & & $43.75 \%$ & $0.00 \%$ \\
\cline { 2 - 4 } & $\mathrm{I}$ & 1 & 8 \\
\cline { 2 - 4 } & & $6.25 \%$ & $50.00 \%$ \\
\hline
\end{tabular}

\begin{tabular}{|c|c|c|c|}
\cline { 3 - 4 } \multicolumn{2}{c|}{} & \multicolumn{2}{c|}{ TAHUN 5 } \\
\cline { 3 - 4 } \multicolumn{2}{c|}{} & $\mathrm{S}$ & $\mathrm{I}$ \\
\hline \multirow{3}{*}{$\begin{array}{c}\text { TAHUN } \\
4\end{array}$} & $\mathrm{~S}$ & 6 & 4 \\
\cline { 2 - 4 } & & $37.50 \%$ & $25.00 \%$ \\
\cline { 2 - 4 } & $\mathrm{I}$ & 2 & 4 \\
\cline { 2 - 4 } & & $12.50 \%$ & $25.00 \%$ \\
\hline
\end{tabular}

\begin{tabular}{|c|c|c|c|}
\cline { 3 - 4 } \multicolumn{2}{c|}{} & \multicolumn{2}{c|}{ TAHUN 3 } \\
\cline { 3 - 4 } \multicolumn{2}{c|}{} & $\mathrm{S}$ & $\mathrm{I}$ \\
\hline $\begin{array}{c}\text { TAHUN } \\
2\end{array}$ & $\mathrm{~S}$ & 6 & 2 \\
\cline { 2 - 4 } & & $37.50 \%$ & $12.50 \%$ \\
\cline { 2 - 4 } & $\mathrm{I}$ & 3 & 5 \\
\cline { 2 - 4 } & & $18.75 \%$ & $31.25 \%$ \\
\hline
\end{tabular}

\begin{tabular}{|c|c|c|c|}
\cline { 3 - 4 } \multicolumn{2}{c|}{} & \multicolumn{2}{c|}{ TAHUN 6 } \\
\cline { 3 - 4 } \multicolumn{2}{c|}{} & $\mathrm{S}$ & $\mathrm{I}$ \\
\hline \multirow{3}{*}{$\begin{array}{c}\text { TAHUN } \\
\end{array}$} & $\mathrm{S}$ & 6 & 2 \\
\cline { 2 - 4 } & & $37.50 \%$ & $12.50 \%$ \\
\cline { 2 - 4 } & $\mathrm{I}$ & 2 & 6 \\
\cline { 2 - 4 } & & $12.50 \%$ & $37.50 \%$ \\
\hline
\end{tabular}

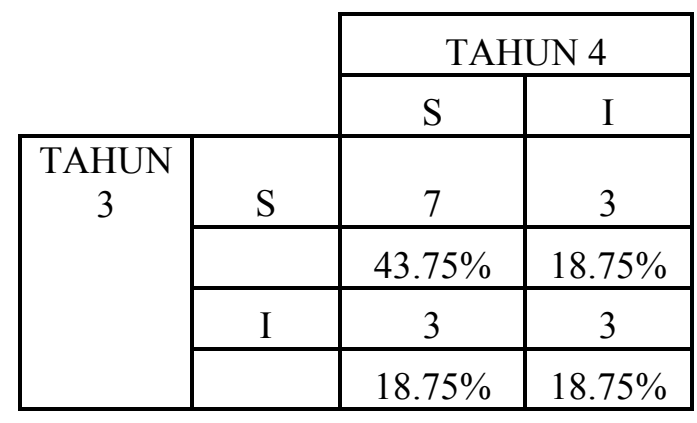

\begin{tabular}{|c|c|c|c|}
\hline \multicolumn{2}{|c|}{ GABUNGAN } & \multicolumn{2}{|c|}{ TAHUN t+1 } \\
\hline & & $\mathrm{S}$ & I \\
\hline \multirow[t]{4}{*}{$\begin{array}{c}\text { TAHUN } \\
\mathrm{t}\end{array}$} & $\mathrm{S}$ & 32 & 11 \\
\hline & & $40.00 \%$ & $13.75 \%$ \\
\hline & $\mathrm{I}$ & 11 & 26 \\
\hline & & $13.75 \%$ & $32.50 \%$ \\
\hline
\end{tabular}

Tabel 14. Probabilita Konsistensi SS dan II menurut Sortino ratio

\begin{tabular}{|c|c|c|c|c|c|c|}
\hline Tahun & $\mathbf{n ( S S )}$ & $\mathrm{n}(\mathrm{SI})$ & $\mathrm{n}(\mathrm{IS})$ & $\mathbf{n}(\mathbf{I I})$ & $\mathrm{n}$ & $\begin{array}{c}\text { Probabilita } \\
\text { Konsistensi }\end{array}$ \\
\hline $1-2$ & $\mathbf{7}$ & $\mathbf{0}$ & 1 & 8 & 16 & $93.75 \%$ \\
$2-3$ & $\mathbf{6}$ & $\mathbf{2}$ & 3 & 5 & 16 & $68.75 \%$ \\
$3-4$ & $\mathbf{7}$ & $\mathbf{3}$ & 3 & 3 & 16 & $62.50 \%$ \\
$4-5$ & $\mathbf{6}$ & $\mathbf{4}$ & 2 & 4 & 16 & $62.50 \%$ \\
$5-6$ & $\mathbf{6}$ & $\mathbf{2}$ & 2 & 6 & 16 & $75.00 \%$ \\
$1-6$ & $\mathbf{3 2}$ & 11 & 11 & $\mathbf{2 6}$ & 80 & $72.50 \%$ \\
\multicolumn{7}{|r|}{}
\end{tabular}


Dengan metode Sortino menunjukkan tingkat konsistensi gabungan yang cukup tinggi. sebesar $72.31 \%$. Persentase tertinggi terjadi pada tahun kedua sebesar $93.75 \%$ dan terendaha pada tahun ke empat dan kelima sebesar $62.50 \%$.

Dalam enam tahun penelitian terdapat 32 reksa dana yang superior dan 26 reksa dana yang inferior secara konsisten dari tahun ke tahun Secara keseluruhan dapat disimpulkan bahwa terdapat konsistensi kinerja reksa dana menurut Sortino ratio dari tahun ke tahun. Ini berarti bahwa investor dapat menggunakan Sortino ratio sebagai salah satu acuan untuk memilih suatu reksa dana.

Tabel 15. Probabilita Konsistensi SS dan II menurut kelima metode tahun 1-6

\begin{tabular}{|c|c|c|c|c|c|c|}
\hline Metode & $\mathbf{n}(\mathbf{S S})$ & $\mathrm{n}(\mathrm{SI})$ & $\mathrm{n}(\mathrm{IS})$ & $\mathbf{n}(\mathbf{I I})$ & $\mathrm{n}$ & $\begin{array}{c}\text { Probabilita } \\
\text { Konsistensi }\end{array}$ \\
\hline Raw Return & $\mathbf{4 2}$ & 7 & 7 & $\mathbf{2 4}$ & 80 & $82.50 \%$ \\
Sharpe & $\mathbf{3 2}$ & 11 & 15 & $\mathbf{2 2}$ & 80 & $67.50 \%$ \\
Treynor & $\mathbf{2 6}$ & 13 & 16 & $\mathbf{2 5}$ & 80 & $63.75 \%$ \\
Jensen & $\mathbf{3 4}$ & 12 & 11 & $\mathbf{2 3}$ & 80 & $71.25 \%$ \\
Sortino & $\mathbf{3 2}$ & 11 & 11 & $\mathbf{2 6}$ & 80 & $72.50 \%$ \\
Total & $\mathbf{1 6 6}$ & $\mathbf{5 4}$ & $\mathbf{6 0}$ & $\mathbf{1 2 0}$ & 400 & $71.50 \%$ \\
\hline
\end{tabular}

Sumber : diolah oleh penulis

Dari tabel diatas dapat disimpulkan bahwa secara keseluruhan terjadi konsistensi kinerja pada 13 reksa dana saham di Indonesia. Rata-rata probabilita konsistensi gabungan selama enam tahun untuk kelima metode yang digunakan adalah $\mathbf{7 1 . 5 0 \% \text { . }}$

Metode yang menunjukkan konsistensi tertinggi adalah Raw Return dengan angka $\mathbf{8 2 . 5 0 \%}$. Untuk investor yang risk taker / yang berani mengambil resiko metode ini dapat dijadikan pilihan pertama. Dengan metode Raw Return, tidak memperhitungkan resiko, akan tetapi hanya menghitung return secara keseluruhan dengan menggunakan rata-rata geometrik. Sehingga untuk investor yang risk taker / yang berani mengambil resiko, maka metode tersebut merupaka pilihan terbaik. Dengan tingkat konsistensi yang sangat tinggi, return yang diberikan akan tinggi.

Metode Sharpe dan Treynor, menghasilkan probabilita konsistensi yang mendekati yaitu $67.50 \%$ dan $63.75 \%$. Sedangkan Metode Jensen alpha dan Sortino, menghasilkan probabilita konsistensi yang juga mendekati yaitu $71.25 \%$ dan $71.50 \%$.

\section{Uji Chi Squared}

\section{Raw Return}

$\mathrm{H}_{0}$ : Tidak terdapat konsistensi antara kinerja reksa dana

$\mathrm{H}_{1}$ : Terdapat konsistensi antara kinerja reksa dana

Taraf nyata $(\alpha)=5 \%$, derajat bebas $(\mathrm{db})=1 \cdot \chi^{2} 5 \%(1)=3,481$. 
Tabel 16. Chi Squared table menurut Raw Return

\begin{tabular}{|c|c|c|c|}
\hline TAHUN t & S & I & JUMLAH \\
\hline $\mathrm{S}$ & 42 & 7 & 49 \\
$\mathrm{I}$ & 7 & 24 & 31 \\
\hline JUMLAH & 49 & 31 & 80 \\
\hline \multicolumn{4}{|c|}{ Sumber : diolah oleh penulis } \\
$\chi_{0}^{2}=\frac{\mathrm{n}(|\mathrm{ad}-\mathrm{bc}|-1 / 2 \mathrm{n})^{2}}{(\mathrm{a}+\mathrm{b})(\mathrm{a}+\mathrm{c})(\mathrm{b}+\mathrm{d})(\mathrm{c}+\mathrm{d})}$ \\
$\chi_{0}^{2}=\frac{80(|(42)(24)-(7)(7)|-1 / 280)^{2}}{(49)(49)(31)(38)}$ \\
$\chi_{0}^{2}=\frac{29.2823}{}$
\end{tabular}

Karena $\chi_{0}^{2}>\chi^{2} 5 \%(1)$ atau $29.28>3.481$ maka $\mathrm{H}_{0}$ ditolak. Jadi dapat ditarik kesimpulan bahwa terdapat konsistensi antara kinerja reksa dana.

\section{Sharpe ratio}

$\mathrm{H}_{0}$ : Tidak terdapat konsistensi antara kinerja reksa dana

$\mathrm{H}_{1}$ : Terdapat konsistensi antara kinerja reksa dana

Taraf nyata $(\alpha)=5 \%$, derajat bebas $(\mathrm{db})=1 \cdot \chi^{2} 5 \%(1)=3,481$.

Tabel 17. Chi Squared table menurut Sharpe ratio

\begin{tabular}{|c|c|c|c|}
\hline TAHUN t & S & I & JUMLAH \\
\hline S & 32 & 11 & 43 \\
I & 15 & 22 & 37 \\
\hline JUMLAH & 47 & 33 & 80 \\
\hline \multicolumn{4}{|c|}{ Sumber : diolah oleh penulis }
\end{tabular}

$$
\begin{aligned}
\chi_{0}^{2} & =\frac{\mathrm{n}(|\mathrm{ad}-\mathrm{bc}|-1 / 2 \mathrm{n})^{2}}{(\mathrm{a}+\mathrm{b})(\mathrm{a}+\mathrm{c})(\mathrm{b}+\mathrm{d})(\mathrm{c}+\mathrm{d})} \\
\chi_{0}^{2} & =\frac{80(|(32)(22)-(11)(15)|-1 / 280)^{2}}{(43)(47)(33)(27)} \\
\chi_{0}^{2} & =8.0725
\end{aligned}
$$

Karena $\chi_{0}^{2}>\chi^{2} 5 \%(1)$ atau $8.0725>3.481$ maka $\mathrm{H}_{0}$ ditolak. Uji chi squared menunjukkan signifikansi yang cukup tinggi sehingga adanya konsistensi antara kinerja reksa dana telah terbukti menurut Sharpe ratio. 


\section{Treynor ratio}

$\mathrm{H}_{0}$ : Tidak terdapat konsistensi antara kinerja reksa dana

$\mathrm{H}_{1}$ : Terdapat konsistensi antara kinerja reksa dana

Taraf nyata $(\alpha)=5 \%$, derajat bebas $(\mathrm{db})=1 \cdot \chi^{2} 5 \%(1)=3,481$.

Tabel 18. Chi Squared table menurut Treynor ratio

\begin{tabular}{|c|c|c|c|}
\hline TAHUN t & S & I & JUMLAH \\
\hline S & 26 & 13 & 39 \\
I & 16 & 25 & 41 \\
\hline JUMLAH & 42 & 38 & 80 \\
\hline \multicolumn{4}{|c|}{ Sumber : diolah oleh penulis }
\end{tabular}

$$
\begin{aligned}
\chi_{0}^{2} & =\frac{\mathrm{n}(|\mathrm{ad}-\mathrm{bc}|-1 / 2 \mathrm{n})^{2}}{(\mathrm{a}+\mathrm{b})(\mathrm{a}+\mathrm{c})(\mathrm{b}+\mathrm{d})(\mathrm{c}+\mathrm{d})} \\
\chi_{0}^{2} & =\frac{80(|(26)(25)-(13)(16)|-1 / 280)^{2}}{(39)(42)(38)(41)} \\
\chi_{0}^{2} & =5.0659
\end{aligned}
$$

Karena $\chi_{0}^{2}>\chi^{2} 5 \%$ (1) atau 5.0659 $>3.481$ maka $\mathrm{H}_{0}$ ditolak. Jadi dapat ditarik kesimpulan bahwa terdapat konsistensi antara kinerja reksa dana.

\section{Jensen alpha}

$\mathrm{H}_{0}$ : Tidak terdapat konsistensi antara kinerja reksa dana

$\mathrm{H}_{1}$ : Terdapat konsistensi antara kinerja reksa dana

Taraf nyata $(\alpha)=5 \%$, derajat bebas $(\mathrm{db})=1 \cdot \chi^{2} 5 \%(1)=3,481$.

Tabel 19. Chi Squared table menurut Jensen alpha

\begin{tabular}{|c|c|c|c|}
\multicolumn{5}{c}{ TAHUN $\mathrm{t}+1$} \\
\hline TAHUN t & $\mathrm{S}$ & $\mathrm{I}$ & JUMLAH \\
\hline S & 34 & 12 & 46 \\
$\mathrm{I}$ & 11 & 23 & 34 \\
\hline JUMLAH & 45 & 35 & 80 \\
\hline
\end{tabular}

Sumber : diolah oleh penulis

$$
\begin{aligned}
\chi_{0}^{2} & =\frac{\mathrm{n}(|\mathrm{ad}-\mathrm{bc}|-1 / 2 \mathrm{n})^{2}}{(\mathrm{a}+\mathrm{b})(\mathrm{a}+\mathrm{c})(\mathrm{b}+\mathrm{d})(\mathrm{c}+\mathrm{d})} \\
\chi_{0}^{2} & =\frac{\mathbf{8 0}(|(34)(23)-(12)(11)|-1 / 280)^{2}}{(46)(45)(35)(34)} \\
\chi_{0}{ }^{2} & =12.0846
\end{aligned}
$$


Karena $\chi_{0}^{2}>\chi^{2} 5 \%(1)$ atau $12.0846>3.481$ maka $\mathrm{H}_{0}$ ditolak. Jadi dapat ditarik kesimpulan bahwa terdapat konsistensi antara kinerja reksa dana.

\section{Sortino ratio}

$\mathrm{H}_{0}$ : Tidak terdapat konsistensi antara kinerja reksa dana

$\mathrm{H}_{1}$ : Terdapat konsistensi antara kinerja reksa dana

Taraf nyata $(\alpha)=5 \%$, derajat bebas $(\mathrm{db})=1 \cdot \chi^{2} 5 \%(1)=3,481$.

Tabel 20. Chi Squared table menurut Sortino ratio

\begin{tabular}{|c|c|c|c|}
\hline TAHUN t & S & I & JUMLAH \\
\hline S & 32 & 11 & 43 \\
I & 11 & 26 & 37 \\
\hline JUMLAH & 43 & 37 & 80 \\
\hline \multicolumn{4}{|c|}{ Sumber : diolah oleh penulis }
\end{tabular}

$$
\begin{aligned}
\chi_{0}^{2} & =\frac{\mathrm{n}(|\mathrm{ad}-\mathrm{bc}|-1 / 2 \mathrm{n})^{2}}{(\mathrm{a}+\mathrm{b})(\mathrm{a}+\mathrm{c})(\mathrm{b}+\mathrm{d})(\mathrm{c}+\mathrm{d})} \\
\chi_{0}^{2} & =\frac{80(|(32)(26)-(11)(11)|-1 / 280)^{2}}{(43)(43)(37)(37)} \\
\chi_{0}^{2} & =14.2299
\end{aligned}
$$

Karena $\chi_{0}^{2}>\chi^{2} 5 \%(1)$ atau $14.2299>3.481$ maka $\mathrm{H}_{0}$ ditolak. Jadi dapat ditarik kesimpulan bahwa terdapat konsistensi antara kinerja reksa dana.

Tabel 21. Uji chi squared menurut kelima metode tahun 1-6

\begin{tabular}{|c|c|c|c|}
\hline Metode & $\chi^{2} 5 \%(1)$ & $\chi_{0}{ }^{2}$ & $\mathrm{H}_{0}$ \\
\hline Raw Return & 3.481 & 29.2823 & Ditolak \\
Sharpe & 3.481 & 8.0725 & Ditolak \\
Treynor & 3.481 & 5.0659 & Ditolak \\
Jensen & 3.481 & 12.0846 & Ditolak \\
Sortino & 3.481 & 14.2296 & Ditolak \\
\hline
\end{tabular}

Dari kelima metode yang digunakan, uji chi squared menyimpulkan bahwa $\mathrm{H}_{0}$ tidak dapat diterima. Jadi hipotesis yang menyatakan tidak terdapat konsistensi antara kinerja reksa dana tidak terbukti.

Ini berarti reksa dana dengan kinerja yang superior di tahun pertama akan tetap memperlihatkan kinerja yang sama di tahun mendatang. Hal ini berlaku sebaliknya, untuk reksa dana dengan kinerja yang inferior akan tetap tidak unggul di tahun berikutnya. Raw return, Sharpe, Treynor, Jensen dan Sortino sama-sama membuktikan bahwa masing-masing metode bisa memperlihatkan konsistensi reksa dana saham di Indonesia. 
Tingkat signifikansi yang cukup tinggi semakin memperkuat keyakinan bahwa memang terdapat konsistensi antara kinerja reksa dana dari tahun ke tahun. Ini berarti data historis dapat dijadikan acuan oleh investor untuk menilai kinerja reksa dana di masa yang akan datang.

Setelah dilakukan uji konsistensi dengan menggunakan metode probabilita dan chi squared selanjutnya akan dibuat suatu peringkat reksa dana.

\section{Peringkat Reksa Dana}

Reksa dana yang menjadi juara menurut raw return menempati posisi superior sebanyak enam kali kali adalah Danareksa Mawar, Fortis Ekuitas, Fortis Pesona, Phinisi Dana Saham, Schroder Prestasi Plus, Si Dana Saham. Sedangkan reksa dana yang memperlihatkan kinerja yang buruk sebanyak enam kali adalah Big Nusantara, Big Palapa, BNI Berkembang dan Nikko Saham Nusantara. Dan reksa dana lainnya memperlihatkan kinerja yang variasi dengan menempati posisi superior dari dua hingga lima kali. Sebagian besar reksa dana dapat menempati posisi superior sebanyak empat kali..

Tabel 22. Peringkat Reksa Dana menurut Raw Return

\begin{tabular}{|c|l|cccccc|}
\hline No & \multicolumn{1}{|c|}{ Nama Reksa Dana } & thn & thn & thn & thn & thn & thn \\
\hline 1 & DANAREKSA MAWAR & S & S & S & S & S & S \\
2 & FORTIS EKUITAS & $\mathrm{S}$ & $\mathrm{S}$ & $\mathrm{S}$ & $\mathrm{S}$ & $\mathrm{S}$ & $\mathrm{S}$ \\
3 & FORTIS PESONA & $\mathrm{S}$ & $\mathrm{S}$ & $\mathrm{S}$ & $\mathrm{S}$ & $\mathrm{S}$ & $\mathrm{S}$ \\
4 & PHINISI DANA SAHAM & $\mathrm{S}$ & $\mathrm{S}$ & $\mathrm{S}$ & $\mathrm{S}$ & $\mathrm{S}$ & $\mathrm{S}$ \\
5 & SCHRODER PRESTASI PLUS & $\mathrm{S}$ & $\mathrm{S}$ & $\mathrm{S}$ & $\mathrm{S}$ & $\mathrm{S}$ & $\mathrm{S}$ \\
6 & SIDANA SAHAM & $\mathrm{S}$ & $\mathrm{S}$ & $\mathrm{S}$ & $\mathrm{S}$ & $\mathrm{S}$ & $\mathrm{S}$ \\
7 & RENCANA CERDAS & $\mathrm{S}$ & $\mathrm{S}$ & $\mathrm{S}$ & $\mathrm{S}$ & $\mathrm{S}$ & $\mathrm{I}$ \\
8 & BAHANA DANA PRIMA & $\mathrm{S}$ & $\mathrm{S}$ & $\mathrm{S}$ & $\mathrm{I}$ & $\mathrm{S}$ & $\mathrm{S}$ \\
9 & PANIN DANA MAKSIMA & $\mathrm{S}$ & $\mathrm{S}$ & $\mathrm{I}$ & $\mathrm{S}$ & $\mathrm{S}$ & $\mathrm{I}$ \\
10 & TRIM KAPITAL & $\mathrm{I}$ & $\mathrm{I}$ & $\mathrm{S}$ & $\mathrm{S}$ & $\mathrm{S}$ & $\mathrm{S}$ \\
11 & ABN AMRO IND. DANA SAHAM & $\mathrm{S}$ & $\mathrm{I}$ & $\mathrm{S}$ & $\mathrm{I}$ & $\mathrm{S}$ & $\mathrm{I}$ \\
12 & MASTER DINAMIS & $\mathrm{I}$ & $\mathrm{I}$ & $\mathrm{I}$ & $\mathrm{S}$ & $\mathrm{I}$ & $\mathrm{S}$ \\
13 & BIG NUSANTARA & $\mathrm{I}$ & $\mathrm{I}$ & $\mathrm{I}$ & $\mathrm{I}$ & $\mathrm{I}$ & $\mathrm{I}$ \\
14 & BIG PALAPA & $\mathrm{I}$ & $\mathrm{I}$ & $\mathrm{I}$ & $\mathrm{I}$ & $\mathrm{I}$ & $\mathrm{I}$ \\
15 & BNI BERKEMBANG & $\mathrm{I}$ & $\mathrm{I}$ & $\mathrm{I}$ & $\mathrm{I}$ & $\mathrm{I}$ & $\mathrm{I}$ \\
16 & NIKKO SAHAM NUSANTARA & $\mathrm{I}$ & $\mathrm{I}$ & $\mathrm{I}$ & $\mathrm{I}$ & $\mathrm{I}$ & $\mathrm{I}$ \\
\hline
\end{tabular}

Reksa dana unggulan adalah reksa dana yang menempati posisi superior minimal tiga kali dari enam tahun periode penelitian. Ada sebelas reksa dana yang diunggulkan menurut raw return. Reksa dana itu adalah Danareksa Mawar, Fortis Ekuitas, Fortis Pesona, Phinisi Dana Saham, Schroder Prestasi Plus, Si Dana Saham yang berhasil mencapai posisi superior 
sebanyak enam kali kali. Dua reksa dana selanjutnya, Rencana Cerdas dan Bahana Dana Prima mempunyai prestasi yang sama baiknya dengan mencapai superior sebanyak lima kali. Trim Kapital mencapai posisi superior sebanyak empat kali dan ABN Amro Indonesia Dana Saham mencapai posisi superior sebanyak 3 kali.

Tabel 23. Peringkat Reksa Dana menurut Sharpe ratio

\begin{tabular}{|c|l|cccccc|}
\hline No & \multicolumn{1}{|c|}{ Nama Reksa Dana } & thn & thn & thn & thn & thn & thn \\
\hline 1 & FORTIS PESONA & -1 & -2 & -3 & -4 & -5 & -6 \\
2 & SCHRODER PRESTASI PLUS & $\mathrm{S}$ & $\mathrm{S}$ & $\mathrm{S}$ & $\mathrm{S}$ & $\mathrm{S}$ & $\mathrm{S}$ \\
3 & FORTIS EKUITAS & $\mathrm{S}$ & $\mathrm{S}$ & $\mathrm{S}$ & $\mathrm{S}$ & $\mathrm{S}$ & $\mathrm{S}$ \\
4 & PHINISI DANA SAHAM & $\mathrm{I}$ & $\mathrm{S}$ & $\mathrm{S}$ & $\mathrm{S}$ & $\mathrm{S}$ \\
5 & RENCANA CERDAS & $\mathrm{I}$ & $\mathrm{S}$ & $\mathrm{S}$ & $\mathrm{S}$ & $\mathrm{S}$ & $\mathrm{S}$ \\
6 & DANAREKSA MAWAR & $\mathrm{S}$ & $\mathrm{S}$ & $\mathrm{S}$ & $\mathrm{S}$ & $\mathrm{S}$ & $\mathrm{I}$ \\
7 & TRIM KAPITAL & $\mathrm{S}$ & $\mathrm{S}$ & $\mathrm{S}$ & $\mathrm{S}$ & $\mathrm{I}$ & $\mathrm{S}$ \\
8 & SIDANA SAHAM & $\mathrm{I}$ & $\mathrm{I}$ & $\mathrm{S}$ & $\mathrm{S}$ & $\mathrm{S}$ & $\mathrm{S}$ \\
9 & BAHANA DANA PRIMA & $\mathrm{I}$ & $\mathrm{S}$ & $\mathrm{S}$ & $\mathrm{S}$ & $\mathrm{I}$ & $\mathrm{S}$ \\
10 & PANIN DANA MAKSIMA & $\mathrm{S}$ & $\mathrm{S}$ & $\mathrm{S}$ & $\mathrm{I}$ & $\mathrm{I}$ & $\mathrm{S}$ \\
11 & MASTER DINAMIS & $\mathrm{S}$ & $\mathrm{S}$ & $\mathrm{I}$ & $\mathrm{S}$ & $\mathrm{S}$ & $\mathrm{I}$ \\
12 & ABN AMRO IND. DANA SAHAM & $\mathrm{I}$ & $\mathrm{I}$ & $\mathrm{I}$ & $\mathrm{S}$ & $\mathrm{I}$ & $\mathrm{S}$ \\
13 & BNI BERKEMBANG & $\mathrm{I}$ & $\mathrm{S}$ & $\mathrm{I}$ & $\mathrm{S}$ & $\mathrm{I}$ \\
14 & NIKKO SAHAM NUSANTARA & $\mathrm{I}$ & $\mathrm{I}$ & $\mathrm{I}$ & $\mathrm{I}$ & $\mathrm{S}$ & $\mathrm{I}$ \\
15 & BIG NUSANTARA & $\mathrm{I}$ & $\mathrm{S}$ & $\mathrm{I}$ & $\mathrm{I}$ & $\mathrm{I}$ \\
16 & BIG PALAPA & $\mathrm{I}$ & $\mathrm{I}$ & $\mathrm{I}$ & $\mathrm{I}$ & $\mathrm{I}$ & $\mathrm{I}$ \\
\hline
\end{tabular}

Sumber : diolah oleh penulis

Reksa dana terbaik menurut Sharpe ratio adalah Fortis Pesona dan Schroder Pestasi Plus yang berhasil mencapai posisi superior sebanyak enam kali. Diikuti Fortis Ekuitas, Phinisi Dana Saham, Rencana Cerdas, Dana Reksa Mawar yang berhasil mencapai posisi superior sebanyak lima kali. Dana untuk reksa dana yang menempati posisi superior sebanyak empat kali adalah reksa dana Trim Kapital, Si Dana Saham, Bahana Dana Prima, dan Panin Dana Maksima. Reksa dana yang mencapai posisi superior hanya sebanyak dua kali adalah Master Dinamis dan ABN Amro Indonesia Saham. Reksa dana yang hanya mencapai posisi superior sebanyak satu kali selama enam tahun pengamatan adalah reksa dana BNI Berkembang dan Nikko Saham Nusantara. Dan reksa Dana yang tidak pernah mencapai posisi superior selama enam tahun pengamatan adalah Big Nusantara dan Big Palapa. 
Tabel 24. Peringkat Reksa Dana menurut Treynor ratio

\begin{tabular}{|c|c|c|c|c|c|c|c|}
\hline No & Nama Reksa Dana & $\begin{array}{c}\text { thn } \\
1\end{array}$ & $\begin{array}{c}\text { thn }- \\
2\end{array}$ & $\begin{array}{c}\text { thn }- \\
3\end{array}$ & thn & thn & $\begin{array}{c}\text { thn - } \\
6\end{array}$ \\
\hline 1 & FORTIS PESONA & $\mathrm{S}$ & $\mathrm{S}$ & $\mathrm{S}$ & $\mathrm{S}$ & $\mathrm{S}$ & $\mathrm{S}$ \\
\hline 2 & PANIN DANA MAKSIMA & $\mathrm{S}$ & $\mathrm{S}$ & I & $\mathrm{S}$ & $\mathrm{S}$ & S \\
\hline 3 & SCHRODER PRESTASI PLUS & $\mathrm{S}$ & S & $\mathrm{S}$ & S & I & $\mathrm{S}$ \\
\hline 4 & TRIM KAPITAL & I & I & $\mathrm{S}$ & $\mathrm{S}$ & $\mathrm{S}$ & $\mathrm{S}$ \\
\hline 5 & FORTIS EKUITAS & $\mathrm{S}$ & I & I & S & $\mathrm{S}$ & $\mathrm{S}$ \\
\hline 6 & PHINISI DANA SAHAM & I & $\mathrm{S}$ & I & $\mathrm{S}$ & S & $\mathrm{S}$ \\
\hline 7 & DANAREKSA MAWAR & S & $\mathrm{S}$ & I & S & I & S \\
\hline 8 & RENCANA CERDAS & $\mathrm{S}$ & $\mathrm{S}$ & $\mathrm{S}$ & $\mathrm{S}$ & I & I \\
\hline 9 & MASTER DINAMIS & I & I & $\mathrm{S}$ & S & I & S \\
\hline 10 & BAHANA DANA PRIMA & S & $\mathrm{S}$ & $\mathrm{I}$ & $\mathrm{I}$ & I & S \\
\hline 11 & SIDANA SAHAM & I & S & $\mathrm{S}$ & $\mathrm{S}$ & I & I \\
\hline 12 & BIG PALAPA & I & I & I & I & I & $\mathrm{S}$ \\
\hline 13 & ABN AMRO IND. DANA SAHAM & I & I & I & I & $\mathrm{S}$ & I \\
\hline 14 & NIKKO SAHAM NUSANTARA & I & I & $\mathrm{S}$ & I & I & I \\
\hline 15 & BIG NUSANTARA & I & I & I & I & I & I \\
\hline 16 & BNI BERKEMBANG & I & I & I & I & I & I \\
\hline
\end{tabular}

Sumber : diolah oleh penulis

Sama seperti metode sebelumnya, Fortis Pesona kembali menjadi juara menurut Treynor ratio. Reksa dana Fortis Pesona unggul berdasarkan metode Sharpe dan Treynor akan tetapi tidak pada metode raw return.

Dengan menggunakan metode Treynor, kinerja reksa dana tidak segemilang dengan metode sebelumnya dengan metode raw return dan Sharpe. Dengan metode Treynor hanya Fortis Pesona yang mampu menduduki posisi superior berturut-turut sebanyak enam kali tahun pengamatan. Dan hanya terdapat dua reksa dana yang mampu mengahasilkan posisi superior sebanyak dua kali, yaitu reksa dana Panin Dana Maksima dan Schroder Prestasi Plus. Reksa dana yang menghasilkan posisi superior sebanyak empat kali adalah reksa dana Trim Kapital, Fortis Ekuitas, Phinisi Dana Saham, Dana Reksa Mawar,dan Rencana Cerdas. Reksa dana yang hanya menghasilkan posisi superior sebanyak tiga kali adalah Master Dinamis, Bahana Dana Prima dan Si Dana Saham. Untuk reksa dana yang berkinerja kurang baik yaitu menghasilkan posisi superior di bawah tiga kali. Di mana terdapat tiga reksa dana yang hanya menghasilkan posisi superior sebanyak satu kali selama enam tahu pengamatan, yaitu Big Palapa, ABN Amro Indonesia Saham, dan Nikko Saham Nusantara. Dan juga terdapat dua reksa dana yang tidak menghasilkan posisi superior selama enam tahun pengamatan adalah Big Palapa dan BNI Dana Berkembang. 
Tabel 25. Peringkat Reksa Dana menurut Jensen alpha

\begin{tabular}{|c|l|cccccc|}
\hline & \multicolumn{1}{|c|}{ Nama Reksa Dana } & thn - & thn - & thn - & thn - & thn - & thn - \\
No & & 1 & 2 & 3 & 4 & 5 & 6 \\
\hline 1 & FORTIS PESONA & $\mathrm{S}$ & $\mathrm{S}$ & $\mathrm{S}$ & $\mathrm{S}$ & $\mathrm{S}$ & $\mathrm{S}$ \\
2 & SCHRODER PRESTASI PLUS & $\mathrm{S}$ & $\mathrm{S}$ & $\mathrm{S}$ & $\mathrm{S}$ & $\mathrm{S}$ & $\mathrm{S}$ \\
3 & TRIM KAPITAL & $\mathrm{I}$ & $\mathrm{S}$ & $\mathrm{S}$ & $\mathrm{S}$ & $\mathrm{S}$ & $\mathrm{S}$ \\
4 & PHINISI DANA SAHAM & $\mathrm{S}$ & $\mathrm{S}$ & $\mathrm{I}$ & $\mathrm{S}$ & $\mathrm{S}$ & $\mathrm{S}$ \\
5 & PANIN DANA MAKSIMA & $\mathrm{S}$ & $\mathrm{S}$ & $\mathrm{S}$ & $\mathrm{S}$ & $\mathrm{S}$ & $\mathrm{I}$ \\
6 & RENCANA CERDAS & $\mathrm{S}$ & $\mathrm{S}$ & $\mathrm{S}$ & $\mathrm{S}$ & $\mathrm{S}$ & $\mathrm{I}$ \\
7 & SIDANA SAHAM & $\mathrm{S}$ & $\mathrm{S}$ & $\mathrm{S}$ & $\mathrm{S}$ & $\mathrm{S}$ & $\mathrm{I}$ \\
8 & FORTIS EKUITAS & $\mathrm{S}$ & $\mathrm{I}$ & $\mathrm{I}$ & $\mathrm{S}$ & $\mathrm{S}$ & $\mathrm{S}$ \\
9 & BAHANA DANA PRIMA & $\mathrm{S}$ & $\mathrm{S}$ & $\mathrm{I}$ & $\mathrm{I}$ & $\mathrm{S}$ & $\mathrm{S}$ \\
10 & DANAREKSA MAWAR & $\mathrm{S}$ & $\mathrm{S}$ & $\mathrm{I}$ & $\mathrm{I}$ & $\mathrm{I}$ & $\mathrm{S}$ \\
11 & MASTER DINAMIS & $\mathrm{I}$ & $\mathrm{I}$ & $\mathrm{S}$ & $\mathrm{I}$ & $\mathrm{I}$ & $\mathrm{S}$ \\
12 & ABN AMRO IND. DANA SAHAM & $\mathrm{S}$ & $\mathrm{I}$ & $\mathrm{I}$ & $\mathrm{I}$ & $\mathrm{S}$ & $\mathrm{I}$ \\
13 & BIG NUSANTARA & $\mathrm{I}$ & $\mathrm{I}$ & $\mathrm{I}$ & $\mathrm{I}$ & $\mathrm{I}$ & $\mathrm{S}$ \\
14 & BNI BERKEMBANG & $\mathrm{I}$ & $\mathrm{I}$ & $\mathrm{I}$ & $\mathrm{I}$ & $\mathrm{S}$ & $\mathrm{I}$ \\
15 & NIKKO SAHAM NUSANTARA & $\mathrm{I}$ & $\mathrm{I}$ & $\mathrm{S}$ & $\mathrm{I}$ & $\mathrm{I}$ & $\mathrm{I}$ \\
16 & BIG PALAPA & $\mathrm{I}$ & $\mathrm{I}$ & $\mathrm{I}$ & $\mathrm{I}$ & $\mathrm{I}$ & $\mathrm{I}$ \\
\hline
\end{tabular}

Sumber : diolah oleh penulis

Reksa dana Fortis Pesona kembali berhasil menjadi reksa dana terbaik menurut Jensen alpha dengan menghasilkan posisi superior sebanyak enam kali selama enam tahun pengamatan. Selain reksa dana Fortis Pesona, reksa dana Schroder Prestasi Plus juga menghasilkan posisi superior sebanyak enam kali berturut-turut selama enam tahun pengamatan. Terdapat lima reksa dana yang mampu menghasilkan posisi superior sebanyak lima kali, yaitu reksa dana Trim Kapital, Phinisi Dana Saham, Panin Dana Maksima, Rencana Cerdas dan Si Dana Saham. Dan terdapat dua reksa dana yang mampu menghasilkan posisi superior sebanyak empat kali yaitu Fortis Ekuitas dan Bahana Dana Prima. Dana Reksa Mawar mampu menghasilkan posisi superior sebanyak tiga kali. Dan terdapat enam reksa dana yang menghasilkan posisi superior biwah tiga kali. Dimana reksa dana Master Dinamis dan ABN Amro Indonesia saham hanya menghasilkan dua kali posisi superior selam enam tahun pengamatan. Reksa dana BNI Berkembang dan Big Nusantara menghasilkan posisi superior sebanyak satu kali selam enam tahun pengamatan dan reksa dana Nikko Saham Nusantara dan Big Palapa tidak menghasilkan posisi superior selama enam tahun pengamatan. 
Tabel 26. Peringkat Reksa Dana menurut Sortino ratio

\begin{tabular}{|c|l|rrrrrcc|}
\hline & & Nhn - & thn - & thn - & thn - & thn - & thn $-~$ \\
No & \multicolumn{1}{|c|}{ Nama Reksa Dana } & 1 & 2 & 3 & 4 & 5 & 6 \\
\hline 1 & FORTIS PESONA & $\mathrm{S}$ & $\mathrm{S}$ & $\mathrm{S}$ & $\mathrm{S}$ & $\mathrm{S}$ & $\mathrm{S}$ \\
2 & SCHRODER PRESTASI PLUS & $\mathrm{S}$ & $\mathrm{S}$ & $\mathrm{S}$ & $\mathrm{S}$ & $\mathrm{S}$ & $\mathrm{S}$ \\
3 & DANAREKSA MAWAR & $\mathrm{S}$ & $\mathrm{S}$ & $\mathrm{S}$ & $\mathrm{S}$ & $\mathrm{S}$ & $\mathrm{S}$ \\
4 & FORTIS EKUITAS & $\mathrm{S}$ & $\mathrm{S}$ & $\mathrm{I}$ & $\mathrm{S}$ & $\mathrm{S}$ & $\mathrm{S}$ \\
5 & BAHANA DANA PRIMA & $\mathrm{S}$ & $\mathrm{S}$ & $\mathrm{S}$ & $\mathrm{I}$ & $\mathrm{S}$ & $\mathrm{S}$ \\
6 & TRIM KAPITAL & $\mathrm{I}$ & $\mathrm{I}$ & $\mathrm{S}$ & $\mathrm{S}$ & $\mathrm{S}$ & $\mathrm{S}$ \\
7 & SIDANA SAHAM & $\mathrm{I}$ & $\mathrm{S}$ & $\mathrm{S}$ & $\mathrm{S}$ & $\mathrm{I}$ & $\mathrm{S}$ \\
8 & RENCANA CERDAS & $\mathrm{S}$ & $\mathrm{S}$ & $\mathrm{S}$ & $\mathrm{S}$ & $\mathrm{I}$ & $\mathrm{I}$ \\
9 & PANIN DANA MAKSIMA & $\mathrm{S}$ & $\mathrm{S}$ & $\mathrm{I}$ & $\mathrm{S}$ & $\mathrm{S}$ & $\mathrm{I}$ \\
10 & MASTER DINAMIS & $\mathrm{I}$ & $\mathrm{I}$ & $\mathrm{I}$ & $\mathrm{S}$ & $\mathrm{I}$ & $\mathrm{S}$ \\
11 & ABN AMRO IND. DANA SAHAM & $\mathrm{I}$ & $\mathrm{I}$ & $\mathrm{S}$ & $\mathrm{I}$ & $\mathrm{S}$ & $\mathrm{I}$ \\
12 & PHINISI DANA SAHAM & $\mathrm{I}$ & $\mathrm{I}$ & $\mathrm{I}$ & $\mathrm{S}$ & $\mathrm{I}$ & $\mathrm{I}$ \\
13 & NIKKO SAHAM NUSANTARA & $\mathrm{I}$ & $\mathrm{I}$ & $\mathrm{S}$ & $\mathrm{I}$ & $\mathrm{I}$ & $\mathrm{I}$ \\
14 & BIG NUSANTARA & $\mathrm{I}$ & $\mathrm{I}$ & $\mathrm{I}$ & $\mathrm{I}$ & $\mathrm{I}$ & $\mathrm{I}$ \\
15 & BIG PALAPA & $\mathrm{I}$ & $\mathrm{I}$ & $\mathrm{I}$ & $\mathrm{I}$ & $\mathrm{I}$ & $\mathrm{I}$ \\
16 & BNI BERKEMBANG & $\mathrm{I}$ & $\mathrm{I}$ & $\mathrm{I}$ & $\mathrm{I}$ & $\mathrm{I}$ & $\mathrm{I}$ \\
\hline
\end{tabular}

Sumber : diolah oleh penulis

Reksa dana yang diunggulkan menurut Sortino ratio adalah Fortis Pesona, Schroder Prestasi Plus dan Dana Reksa Mawar dengan menduduki posisi superior sebanyak enam kali berturut-turut selama enam tahun pengamatan. Sebelumnya dengan metode Treynor dan Jensen alpha, Dana Reksa Mawar hanya menghasilkan posisi superior sebanyak tiga kali. Terdapat dua reksa dana yang menghasilkan superior sebanyak liam kali selama enam tahun pengamatan yaitu Fortis Ekuitas dan Bahana Dana Prima. Sedangkan reksa dana Trim Kapital, Si Dana Saham, Rencana Cerdas, dan Panin Dana Maksima menghasilkan posisi superior sebanyak empat kali selama enam tahun pengamatan. Dengan metode Sortino terdapat tujuh reksa dana yang berkinerja buruk. Dimana terdapat dua menghasilkan posisi superior sebanyak dua kali yaitu Master Dinamis dan ABN Amro Indonesia Saham dan terdapat dua reksa dana pula yang menghasilkan satu posisi superior selam enam tahun pengamatan, yaitu reksa dana Phinisi Dana Saham Dana Nikko Saham Nusantara. Tiga reksa dana yang tidak menghasilkan posisi superior selama enam tahun pengamatan adalah Big Nusantara, Big Palapa dan BNI Berkembang.

Setelah mengetahui reksa dana mana yang unggul menurut masing-masing metode, tabel dibawah ini akan memperlihatkan peringkat reksa dana menurut kelima metode yang digunakan. 
Tabel 27. Peringkat Reksa Dana menurut Kelima Metode

\begin{tabular}{|c|l|c|c|c|c|c|}
\hline No & \multicolumn{1}{|c|}{ Nama Reksa Dana } & $\begin{array}{c}\text { Raw } \\
\text { Return }\end{array}$ & Sharpe & Treynor & Jensen & Sortino \\
\hline 1 & FORTIS PESONA & $\mathrm{o}$ & $\mathrm{o}$ & $\mathrm{o}$ & $\mathrm{o}$ & $\mathrm{o}$ \\
2 & SCHRODER PRESTASI PLUS & $\mathrm{o}$ & $\mathrm{o}$ & $\mathrm{o}$ & $\mathrm{o}$ & $\mathrm{o}$ \\
3 & DANAREKSA MAWAR & $\mathrm{o}$ & $\mathrm{o}$ & $\mathrm{o}$ & $\mathrm{o}$ & $\mathrm{o}$ \\
4 & FORTIS EKUITAS & $\mathrm{o}$ & $\mathrm{o}$ & $\mathrm{o}$ & $\mathrm{o}$ & $\mathrm{o}$ \\
5 & TRIM KAPITAL & $\mathrm{o}$ & $\mathrm{o}$ & $\mathrm{o}$ & $\mathrm{o}$ & $\mathrm{o}$ \\
6 & PANIN DANA MAKSIMA & $\mathrm{o}$ & $\mathrm{o}$ & $\mathrm{o}$ & $\mathrm{o}$ & $\mathrm{o}$ \\
7 & SIDANA SAHAM & $\mathrm{o}$ & $\mathrm{o}$ & $\mathrm{o}$ & $\mathrm{o}$ & $\mathrm{O}$ \\
8 & RENCANA CERDAS & $\mathrm{o}$ & $\mathrm{o}$ & $\mathrm{o}$ & $\mathrm{o}$ & $\mathrm{o}$ \\
9 & BAHANA DANA PRIMA & $\mathrm{o}$ & $\mathrm{o}$ & $\mathrm{o}$ & $\mathrm{o}$ & $\mathrm{o}$ \\
10 & PHINISI DANA SAHAM & $\mathrm{o}$ & $\mathrm{o}$ & $\mathrm{o}$ & $\mathrm{o}$ & $\mathrm{x}$ \\
11 & MASTER DINAMIS & $\mathrm{x}$ & $\mathrm{x}$ & $\mathrm{o}$ & $\mathrm{x}$ & $\mathrm{x}$ \\
12 & ABN AMRO IND. DANA SAHAM & $\mathrm{x}$ & $\mathrm{x}$ & $\mathrm{x}$ & $\mathrm{x}$ & $\mathrm{x}$ \\
13 & BIG NUSANTARA & $\mathrm{x}$ & $\mathrm{x}$ & $\mathrm{x}$ & $\mathrm{x}$ & $\mathrm{x}$ \\
14 & BNI BERKEMBANG & $\mathrm{x}$ & $\mathrm{x}$ & $\mathrm{x}$ & $\mathrm{x}$ & $\mathrm{x}$ \\
15 & NIKKO SAHAM NUSANTARA & $\mathrm{x}$ & $\mathrm{x}$ & $\mathrm{x}$ & $\mathrm{x}$ & $\mathrm{x}$ \\
16 & BIG PALAPA & $\mathrm{x}$ & $\mathrm{x}$ & $\mathrm{x}$ & $\mathrm{x}$ & $\mathrm{x}$ \\
\hline
\end{tabular}

Keterangan :

$\mathrm{o}=$ reksa dana unggulan

$\mathrm{x}=$ bukan reksa dana unggulan

Dari 16 reksa dana saham yang diteliti dengan lima metode penilaian kinerja selama 6 tahun, terdapat sembilan reksa dana unggulan yaitu Fortis Pesona, Schroder Prestasi Plus, Dana Reksa Mawar, Fortis Ekuitas, Trim Kapital, Panin Dana Maksima, Si Dana Saham, Rencana Cerdas dan Bahana Dana Prima. Kesembilan reksa dana merupakan reksa dana terbaik menurut raw return, Sharpe, Treynor, Jensen dan Sortino.

Sedangkan reksa dana yang tidak menghasilkan kinerja yang baik menurut kelima metode adalah Phinisi Dana Saham, Master Dinamis, ABN Amro Indonesia Saham, Big Nusantara, BNI Berkembang, Nikko Saham Nusantara dan Big Palapa. 


\section{KESIMPULAN DAN SARAN}

\section{Kesimpulan}

1) Kinerja reksa dana saham di Indonesia pada periode 2002-2007 adalah sebesar $56.25 \%$ atau sebanyak 9 reksa dana saham yang dinyatakan superior, sedangkan sisanya sebanyak 7 reksa dana saham atau sebesar $43.75 \%$ dinyatakan inferior.

2) Terdapat konsistensi kinerja reksa dana saham menurut raw return, metode Sharpe, Treynor, Jensen dan Sortino periode 2002-2007 dengan rata-rata probabilita konsistensi sebesar $71.50 \%$

3) Peringkat reksa dana saham menurut raw return, metode Sharpe, Treynor, Jensen dan Sortino periode 2002-2007 adalah Fortis Pesona, Schroder Prestasi Plus, Dana Reksa Mawar, Fortis Ekuitas, Trim Kapital, Panin Dana Maksima, Si Dana Saham, Rencana Cerdas dan Bahana Dana Prima.

\section{Saran}

Penelitian yang dilakukan saat ini, dengan pembatasan pada reksa dana saham saja, waktu operasional reksa dana yang masih singkat, metode perhitungan kinerja yang terbatas tentu saja mempunyai banyak kekurangan. Penelitian yang lebih sempurna di masa yang akan datang dapat dilakukan dengan :

1) Memperbanyak jumlah reksa dana yang diteliti.

2) Menggunakan data historis yang lebih panjang.

3) Menggunakan metode-metode yang lebih banyak dan bervariasi.

Melihat pentingnya pemeringkat kinerja reksa dana dan untuk menciptakan suatu pasar yang lebih baik, sebaiknya Badan Pengawasan Pasar Modal dan Lembaga Keuangan (BAPEPAM-LK) berkerja sama dengan pihak independen untuk membentuk sebuah badan yang mengevaluasi kinerja reksa dana yang ada di Indonesia. Sehingga memberikan informasi yang lebih jelas dan independen kepada investor.

\section{DAFTAR PUSTAKA}

Aritonang R., \& Lerbin R. (1998). Penelitian Pemasaran. UPT Penelitian Universitas Tarumanagara, Jakarta.

Eko Priyo Pratomo \& Ubaidillah Nugraha. (2000). Reksa Dana : Solusi Perencanaan Investasi di Era Modern. PT. Gramedia Pustaka Utama.

Fabozzi, Frank J. \& Franco Modigliani. (2003). Capital Markets, $3^{\text {rd }}$ Edition. New Jersey: Prentice-Hall International Inc.

Iqbal Hasan. (2004). Analisis Data Penelitian dengan Statistik. PT. Bumi Aksara. 
Jensen, Michael C., (1967). The Performance of Mutual Funds in the Period of 1945-1964. Journal of Finance, Vol.23, No 2.

Jorion, Philippe. (2002). Value at Risk, $2^{\text {nd }}$ Edition. McGraw-Hill Companies Inc.

Kritzman, Mark. (1993) What Practitioners Need to Know...About Risk and Return. Financial Analyst Journal.

Reilly, Frank K., \& Edgar A. Norton. (2003). Investments, $6^{\text {th }}$ Edition. South Western: Thomson.

Sharpe, Alexander., \& Bailey. (1999). Investments, $6^{\text {th }}$ Edition. New Jersey: Prentice-Hall International Inc.

Sharpe, William F. (1994). The Sharpe Ratio. Journal of Portfolio Management, Fall.

Singgih Riphat. (1996). Prospek Reksadana dalam Kerangka Pengembangan Pasar Modal di Indonesia. Jurnal Keuangan dan Moneter Vol. 3 No. 1, April.

Sortino, Frank A., \& Lee N. Price. (1994). Performance Measurement in a Downside risk Framework.. Journal of Investing, Fall.

Sortino, Frank A., \& Hal J. Forsey. 1996). On the Use and Misuse of Downside Risk. Journal of Portfolio Management, Winter. 